
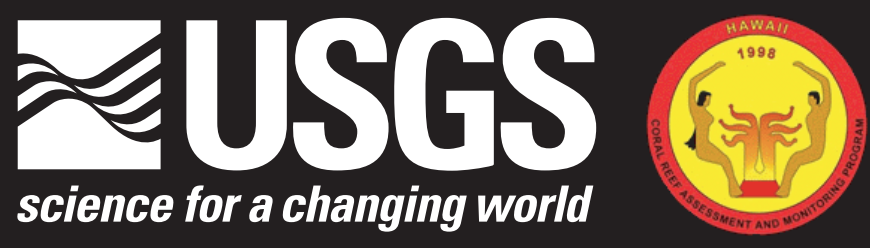

In cooperation with the Hawai'i Coral Reef Assessment and Monitoring Program (CRAMP), Hawai'i Institute of Marine Biology, University of Hawai'i

\title{
Biological Survey in Support of the USGS Turbidity and Sediment Baseline Survey on South Moloka'i Reef Flat, April 2005
}

By Rodgers, K.S., Jokiel, P.L., Smith, W.R., Farrell, F., Uchino, K.

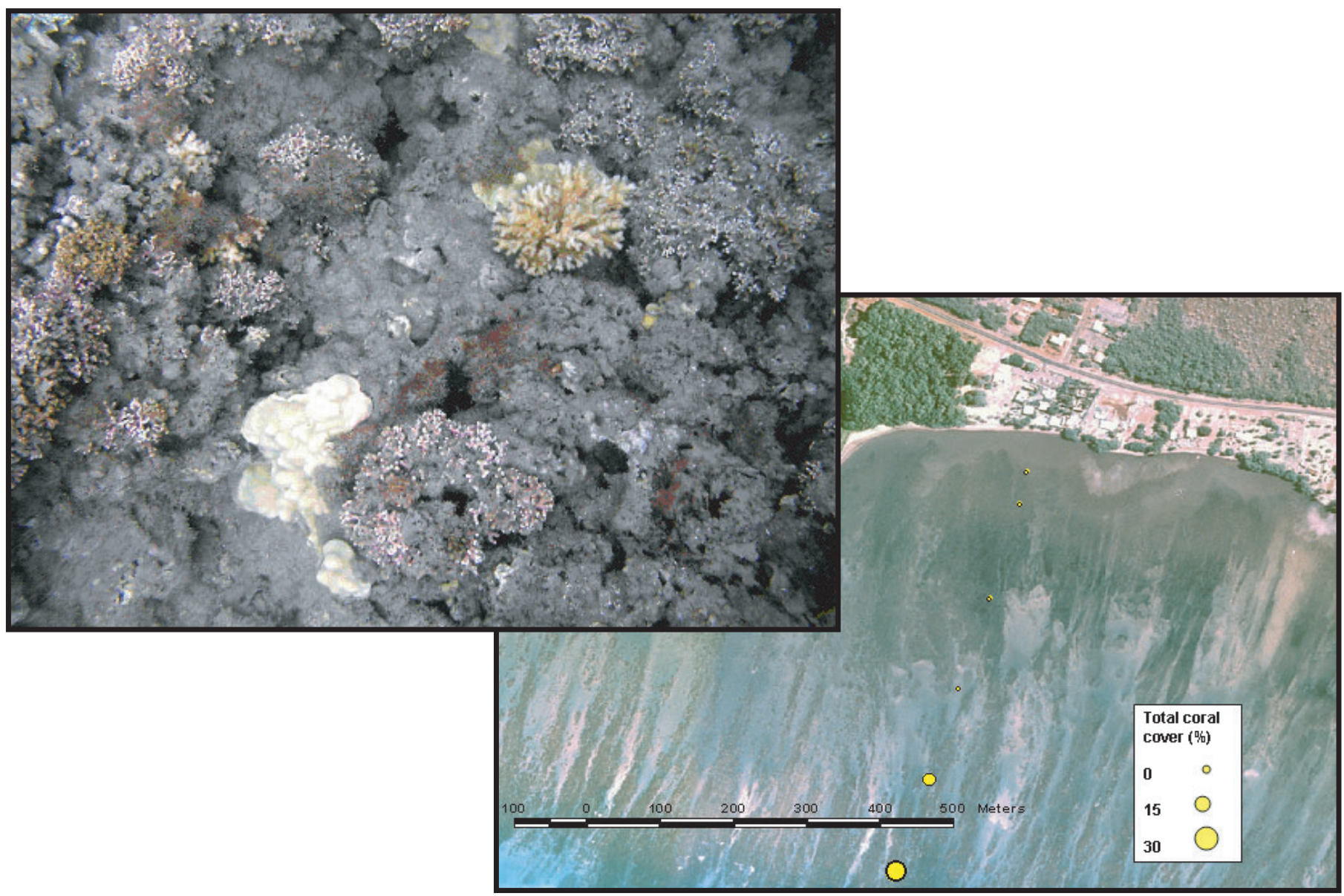

Any use of trade, firm, or product names is for descriptive purposes only and does not

imply endorsement by the U.S. Government

\section{Open-File Report 2005-1361}




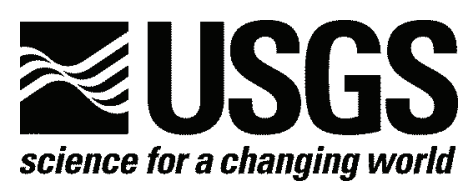

In cooperation with the Hawai'i Coral Reef Assessment and Monitoring Program (CRAMP), Hawai'i Institute of Marine Biology, University of Hawai'i

\section{Biological Survey in Support of the USGS Turbidity and Sediment Baseline Survey on South Moloka'i Reef Flat, April 2005}

By Rodgers, K.S., Jokiel, P.L., Smith, W.R., Farrell, F., Uchino, K.

Open-File Report 2005-1361 


\title{
U.S. Department of the Interior \\ U.S. Geological Survey
}

\section{U.S. Department of the Interior \\ Gale A. Norton, Secretary}

\author{
U.S. Geological Survey \\ P. Patrick Leahy, Acting Director
}

U.S. Geological Survey, Reston, Virginia 2005

Revised and reprinted: 2005

For product and ordering information:

World Wide Web: http://www.usgs.gov/pubprod

Telephone: 1-888-ASK-USGS

For more information on the USGS-the Federal source for science about the Earth, its natural and living resources, natural hazards, and the environment:

World Wide Web: http://www.usgs.gov

Telephone: 1-888-ASK-USGS

Citation for this report:

Rodgers, K.S., Jokiel, P.L., Smith, W.R., Farrell, F., and Uchino, K., 2005, Biological Survey

in Support of the USGS Turbidity and Sediment Baseline Survey on South Moloka'i

Reef Flat, April 2005. USGS Open-File Report 2005-1361, 30 p.

Any use of trade, product, or firm names is for descriptive purposes only and does not imply endorsement by the U.S. Government.

Although this report is in the public domain, permission must be secured from the individual copyright owners to reproduce any copyrighted material contained within this report. 


\section{Contents}

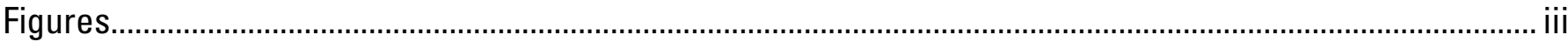

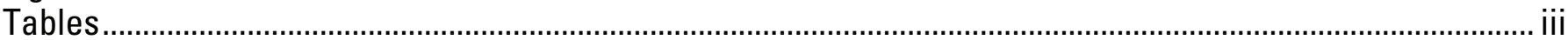

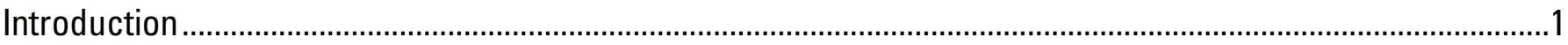

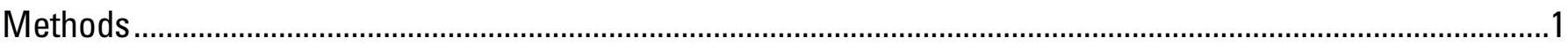

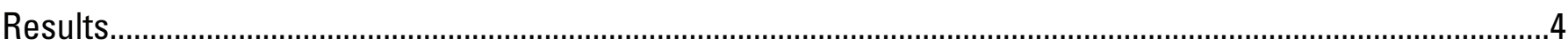

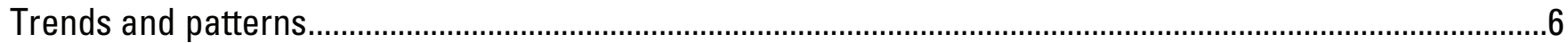

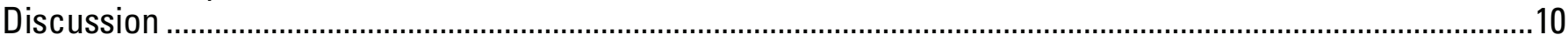

Summary …

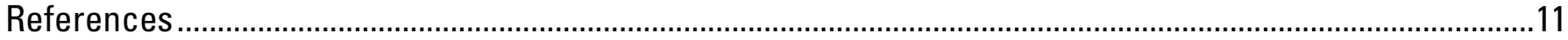

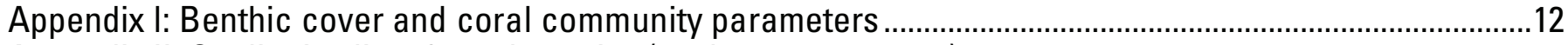

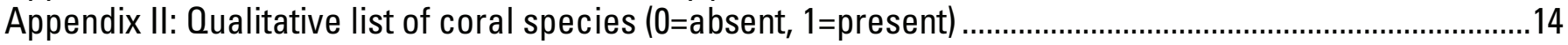

Appendix III: Qualitative list of algal species ( $0=$ =absent, $1=$ present) ..............................................................16

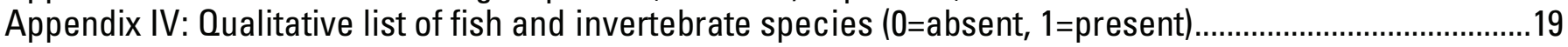

Appendix V: Summary of coral survey parameters with example images ...................................................22

\section{Figures}

Figure 1. Image map showing study area along the south coast of Moloka'i............................................... 2

Figure 2. Schematic diagram showing photographic sampling method. ..................................................... 3

Figure 3. Image map showing USGS, CRAMP, and RAT transect locations between Kamalo and

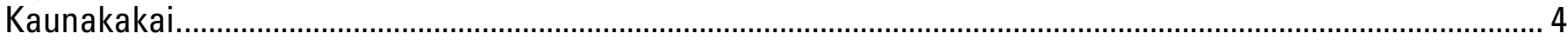

Figure 4. Graph showing percent coral cover at USGS survey sites........................................................ 5

Figure 5. Graph showing species richness at USGS survey sites........................................................... 6

Figure 6. Graph showing Detrended Correspondence Analysis (DCA) of select benthic cover showing quantitative relationships between the sites as defined by biotic composition. ........................................... 8

Figure 7. Aerial image showing coral cover at USGS survey sites off Kamiloloa (transect H)........................ 9 Figure 8. Aerial image showing coral cover at USGS survey sites on reef flat and eight RAT sites on reef face off Kakahai'a (transect D)................................................................................................................... Figure 9. Generalized cross-section of the south Moloka'i reef showing coral cover increasing with distance from shore.

\section{Tables}

Table 1. Summary data for CRAMP long-term monitoring and rapid assessment technique (RAT) stations off South Moloka'i. 


\title{
Biological Survey in Support of the USGS Turbidity and Sediment Baseline Survey on South Moloka'i Reef Flat, April 2005
}

\author{
By Rodgers, K.S. ${ }^{1}$, Jokiel, P.L. ${ }^{1}$, Smith, W.R. ${ }^{1}$, Farrell, F. ${ }^{1}$, and Uchino, K. ${ }^{1}$
}

\section{Introduction}

A biological survey of the South Moloka'i coral reef was undertaken by the University of Hawai'i Coral Reef Assessment and Monitoring Program (CRAMP) in support of the extensive effort by USGS to characterize sediment dynamics on the south Moloka'i reef flat. The experimental design and sampling sites for the USGS project were established primarily to document patterns of sediment input, distribution and sediment output on the south Moloka'i reef in the area between Kamalo and Kaunakakai. The overall project experimental design was not driven by biological questions, but rather was designed to establish baseline data for water quality data and sediment distribution. The focus of the biological support component was to describe the biological condition at each of the USGS sediment/water quality sampling sites. The biological data were taken in a manner that will enable a future quantitative evaluation of possible changes in the benthos at each site over time. These data can then be related to any changes in turbidity, suspended sediment concentrations, or sediment on the reef flat.

\section{Methods}

On May 6-9, 2005, biological surveys were conducted at each sampling point along the nine shore-normal survey transects that had been established on the reef flat between Kamalo and Kaunakakai by the USGS (Figure 1). The location of each site had been marked with a numbered buoy by the USGS team. A biological survey was undertaken in order to provide biological information on the benthos at each sampling point.

Along with time, cost and effort, selection criteria for benthic sampling should include the population of interest, statistical power, accuracy, precision, sources of variability, the focus of the study and the spatial scale involved. A photographic transecting method was selected for use in this research for the following reasons:

\footnotetext{
${ }^{1}$ Hawai'i Coral Reef Assessment and Monitoring Program (CRAMP), University of Hawai' i, Hawai'i Institute of Marine Biology, PO Box 1346, Kaneohe, HI 96744
} 


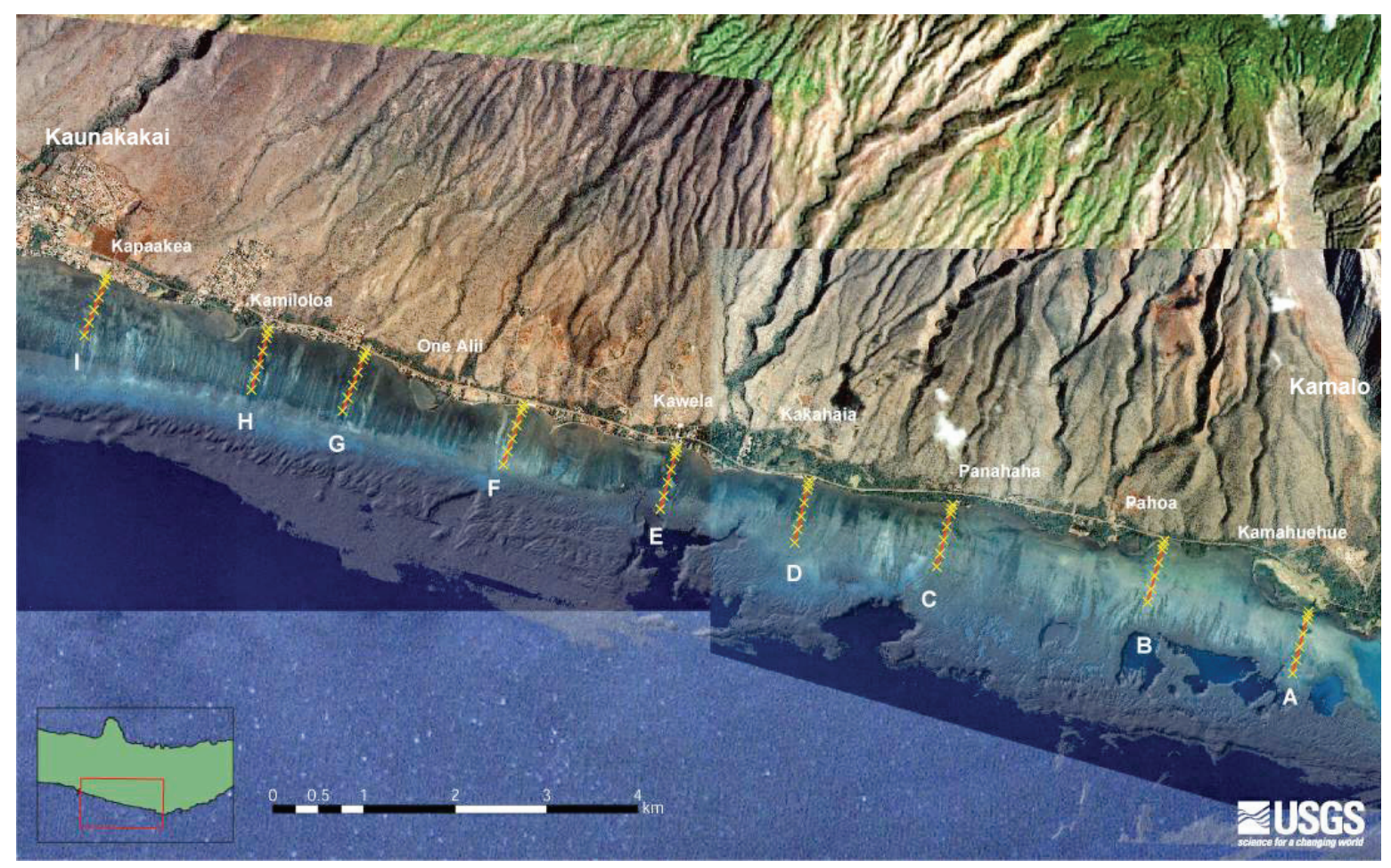

Figure 1. Image map showing study area along the south coast of Moloka'i. Biological survey data were collected along nine transects, with six stations at each, from Kamalo to Kaunakakai.

Method selection criteria required data compatibility with sites incorporated into this study (Jokiel et al. 2001).

A quantitative method is critical to most advanced statistical procedures.

Although the data input and analysis can be more time intensive, the photographic method is not restrained by the limitations of many other benthic sampling methods such as high observer variability or vertical overlap.

Precision using this photographic technique was determined to be high ( $~ 95 \%$ similarity among observers) compared to in situ observations (Brown et al. 2003).

Use of a camera monopod does not negatively impact the benthos.

Photographic methods allow for archiving and data verification, which is critical in addressing further questions, and in quality control.

The standard procedure developed by NOAA for ground truthing of reef maps in Hawai'i involves estimation of benthic cover in a $7 \mathrm{~m}$ radius from an accurately established GPS point. The geomorphological structure is determined and the biological cover type is estimated in $10 \%$ increments. The procedure developed for this study involved taking a large number of randomly selected digital images from within the $7 \mathrm{~m}$ radius in order to describe the benthic populations at each site in a statistically valid manner. This procedure will allow future comparisons and detection of change. A total of 40 digital photos were taken within the $7 \mathrm{~m}$ radius at each of the 54 stations established by GPS and marked by buoys. The sampling circle had a center point located $3.5 \mathrm{~m}$ to the west (down-current) of each buoy in order to avoid interfering with instrumentation that was located up-current (east) of some of the buoys. Thus, the $7 \mathrm{~m}$ diameter sampling circle was tangent to the 
transect line at the east edge. Within each sampling circle a total of 40 haphazardly selected images were taken following the pattern shown in Figure 2. These high resolution digital images encompassed a $20 \mathrm{~m}^{2}$ subsample of the $38.7 \mathrm{~m}^{2}$ area. A subset of 20 randomly selected images was chosen from the 40 images taken at each site.

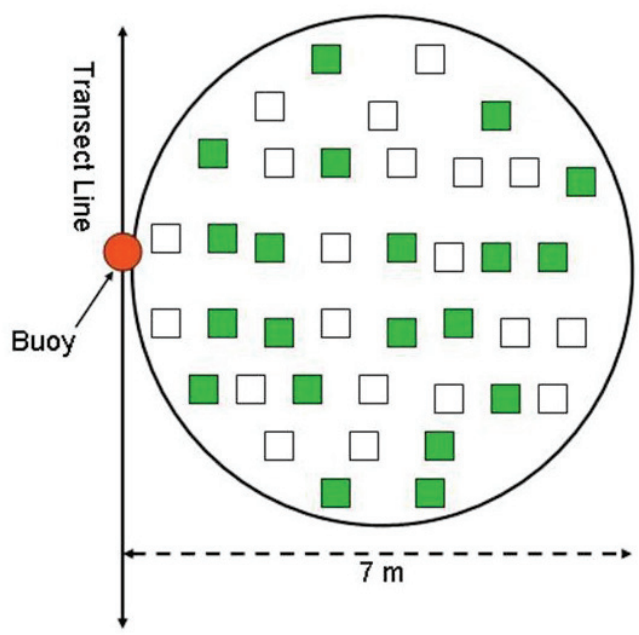

Figure 2. Schematic diagram showing photographic sampling method. A total of 40 digital images were taken haphazardly inside of the $7 \mathrm{~m}$ transect circle following a row order of $2,3,7,8,8,7,3,2$ pattern. Subsequently, a random subset of 20 images (green) was analyzed.

An Olympus 5050 zoom digital camera with an Olympus PT050 underwater housing mounted to an aluminum monopod frame, $1.7 \mathrm{~m}$ from the substrate provides a $50 \mathrm{x} 50 \mathrm{~cm}$ image. A $6 \mathrm{~cm}$ bar attached to the monopod provides a measurement scale. A temporal series of photoquads previously taken in the general vicinity established statistically, that low variability exists within stations (Brown et al. 2003). Therefore 20 randomly selected images from each area is more than adequate for this study. This level of sampling should be adequate to detect changes in these areas in future years. All of the images taken during the survey and data in the Appendices are archived with the National Oceanographic and Atmospheric Administration's (NOAA) National Oceanographic Data Center (NODC) which archives and provides public access to oceanographic and coastal data. Additional data collected during field surveys include a complete species lists (Appendices II, III, IV) and other in situ data observed using a dive mask or viewing box.

Values generated using this method are compatible with the long term monitoring CRAMP protocol and the rapid assessment techniques (RATs) used by the Coral Reef Assessment and Monitoring Program (Jokiel et al. 2001; Brown et al. 2003). Long-term CRAMP monitoring stations are established on hardbottom substrate with ten randomly selected $10 \mathrm{~m}$ permanent transects with endpoints marked by short stainless steel pins. CRAMP RAT stations are selected by generating 100 random points onto habitat maps using GPS Pathfinder Office 2.8. Navigational GPS is used in the field to determine the exact position of each point, marking the beginning of each $10 \mathrm{~m}$ transect. Both the long-term CRAMP monitoring and CRAMP RAT methodology also use 20 digital images from each transect to estimate benthic coverage. Photos generated in this survey were processed using the same methodology as existing monitoring and assessment data. Images are downloaded and imported into PhotoGrid to tabulate coral and benthic substrate types at each of 50 randomly selected points per image. Total mean percent coral cover by station, mean percent coral cover by species within a station, and species richness (number of species per transect) are calculated in Excel. Coral diversity was calculated using the Shannon-Weaver diversity index. 
Long-term CRAMP monitoring stations installed in 1999 off south Moloka'i include a pair of $3 \mathrm{~m}$ and $10 \mathrm{~m}$ stations located at Kamiloloa and Kamalo. RAT sites surveyed in 2002 are located off Kakahai'a and Kamiloloa. Kamalo and Kamiloloa sites vary from 959 m to 1775 m offshore, with depths ranging from 3 to $10 \mathrm{~m}$. Kakahai'a sites vary from $725 \mathrm{~m}$ to $1700 \mathrm{~m}$ offshore, with depths ranging from 5 to $19 \mathrm{~m}$. These sites, as well as the sites for the current survey are shown in Table 1 and Figure 3.

Table 1. Summary data for CRAMP long-term monitoring and rapid assessment technique (RAT) stations off South Moloka'i

\begin{tabular}{|lrrrrrrr|}
\hline Survey Type & Site & Station & $\begin{array}{c}\text { Distance } \\
\text { from shore }\end{array}$ & $\begin{array}{c}\text { Depth } \\
\text { (m) }\end{array}$ & $\begin{array}{c}\text { Total } \\
\text { Coral } \\
\text { cover }\end{array}$ & $\begin{array}{c}\text { Species } \\
\text { Richness }\end{array}$ & $\begin{array}{c}\text { Diversity } \\
\text { (H') }\end{array}$ \\
\hline RAT & Kakahai'a & 1 & 1,657 & 19.1 & 85.8 & 2 & 0.69 \\
RAT & Kakahai'a & 2 & 1,420 & 9.7 & 69.8 & 2 & 0.40 \\
RAT & Kakahai'a & 3 & 1,684 & 19.1 & 61.4 & 3 & 0.83 \\
RAT & Kakahai'a & 4 & 1,392 & 10.3 & 53.2 & 4 & 0.96 \\
RAT & Kakahai'a & 5 & 1,059 & 5.2 & 53.4 & 6 & 0.81 \\
RAT & Kakahai'a & 6 & 877 & 5.2 & 57.6 & 5 & 1.24 \\
RAT & Kakahai'a & 7 & 1,362 & 18.5 & 69.2 & 4 & 0.81 \\
RAT & Kakahai'a & 8 & 1,284 & 8.2 & 61.2 & 4 & 0.95 \\
RAT & Kakahai'a & 9 & 739 & 3.3 & 42.6 & 4 & 0.83 \\
RAT & Kamiloloa & 1 & 1,208 & 9.1 & 3.8 & 4 & 1.11 \\
RAT & Kamiloloa & 2 & 1,055 & 4.2 & 10.0 & 3 & 0.69 \\
RAT & Kamiloloa & 3 & 1,211 & 3.6 & 6.2 & 3 & 0.28 \\
Monitoring & Kamiloloa & $3 \mathrm{~m}$ & 959 & 3.0 & 3.3 & 2 & 0.22 \\
Monitoring & Kamiloloa & $10 \mathrm{~m}$ & 1,138 & 10.0 & 1.3 & 1 & 1.14 \\
Monitoring & Kamalo & $3 \mathrm{~m}$ & 1,320 & 3.0 & 55.9 & 5 & 0.76 \\
Monitoring & Kamalo & $10 \mathrm{~m}$ & 1,762 & 10.0 & 51.2 & 5 & 1.14 \\
\hline
\end{tabular}

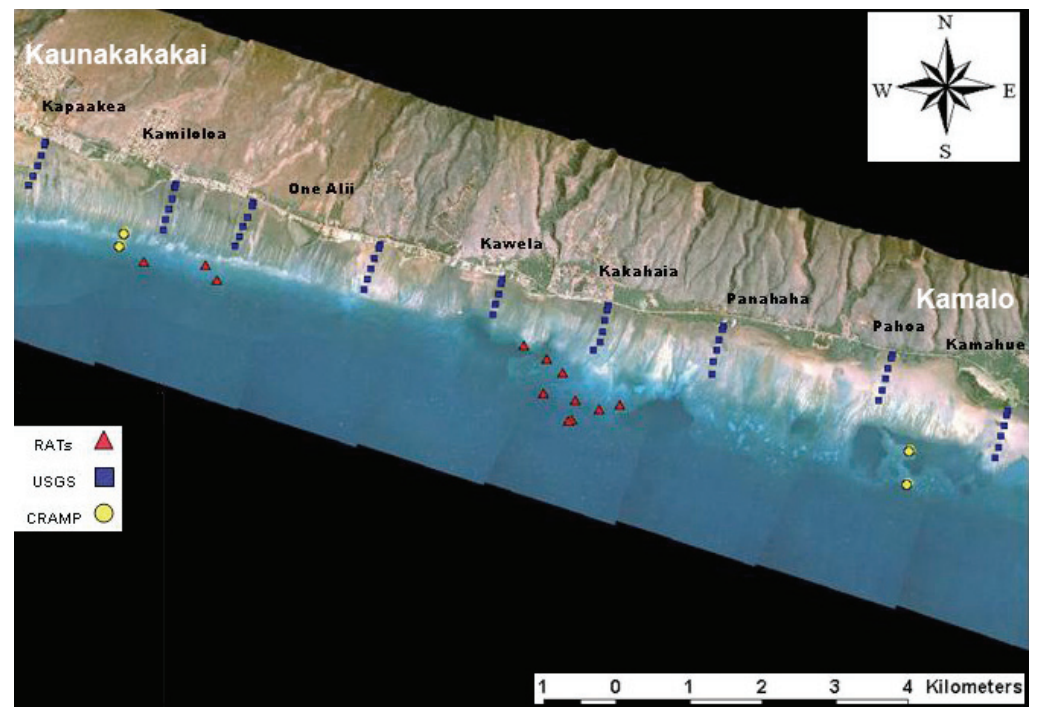

Figure 3. Image map showing USGS, CRAMP, and RAT transect locations between Kamalo and Kaunakakai.

\section{Results}

No corals were recorded at any of the nine USGS transects at $50 \mathrm{~m}, 100 \mathrm{~m}$, and $250 \mathrm{~m}$ from shore. Averages across transects showed total coral cover increased with distance from shore from 
$1.6 \%$ at $400 \mathrm{~m}$, to $7.4 \%$ at $550 \mathrm{~m}$, to $11.2 \%$ at $700 \mathrm{~m}$ (Figure 4 ). Coral cover ranged from $0 \%$ at most inshore sites to a high of $42 \%$ at the $700 \mathrm{~m}$ site of transect E, located at Kawela.

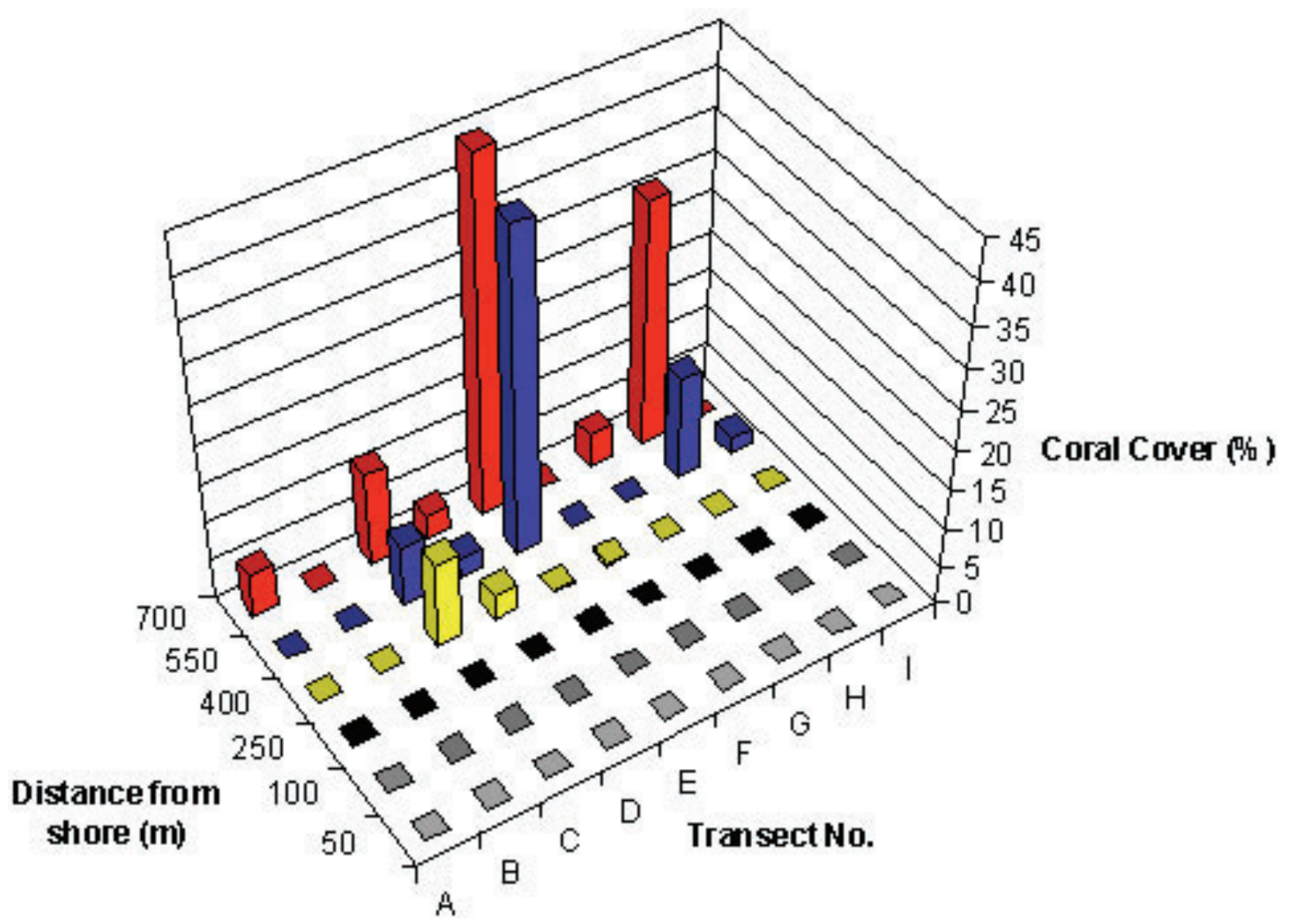

Figure 4. Graph showing percent coral cover at USGS survey sites.

Diversity and species richness are often used to describe coral reef community structure and environmental condition. Richness indicates the number of species, while diversity takes into account both the number of species and their abundance. However, diversity is low in Hawai'i and may not be an appropriate indicator of environmental conditions in this region. Hawaiian communities are often dominated by a few primary species where diversity does not decline with decreasing latitude as in other regions (Grigg 1983). Due to geographic isolation, corals in Hawai'i are depauparate relative to the Indo-West Pacific. Only 16 genera containing 42 species have been documented from the Main Hawaiian Islands. Difficult field identification and detection of cryptic or deep species and low digital resolution may also reduce the predictive ability of diversity. However, coral richness can be a useful measure in describing community structure and reef condition.

Overall, we recorded 13 coral species along the USGS transects (Appendix II). A total of 11 coral species were recorded from photographic images. The highest coral richness (10 species) was found at $700 \mathrm{~m}$ from shore on transect E, located at Kawela (Figure 5). Coral diversity was also highest at this station. 


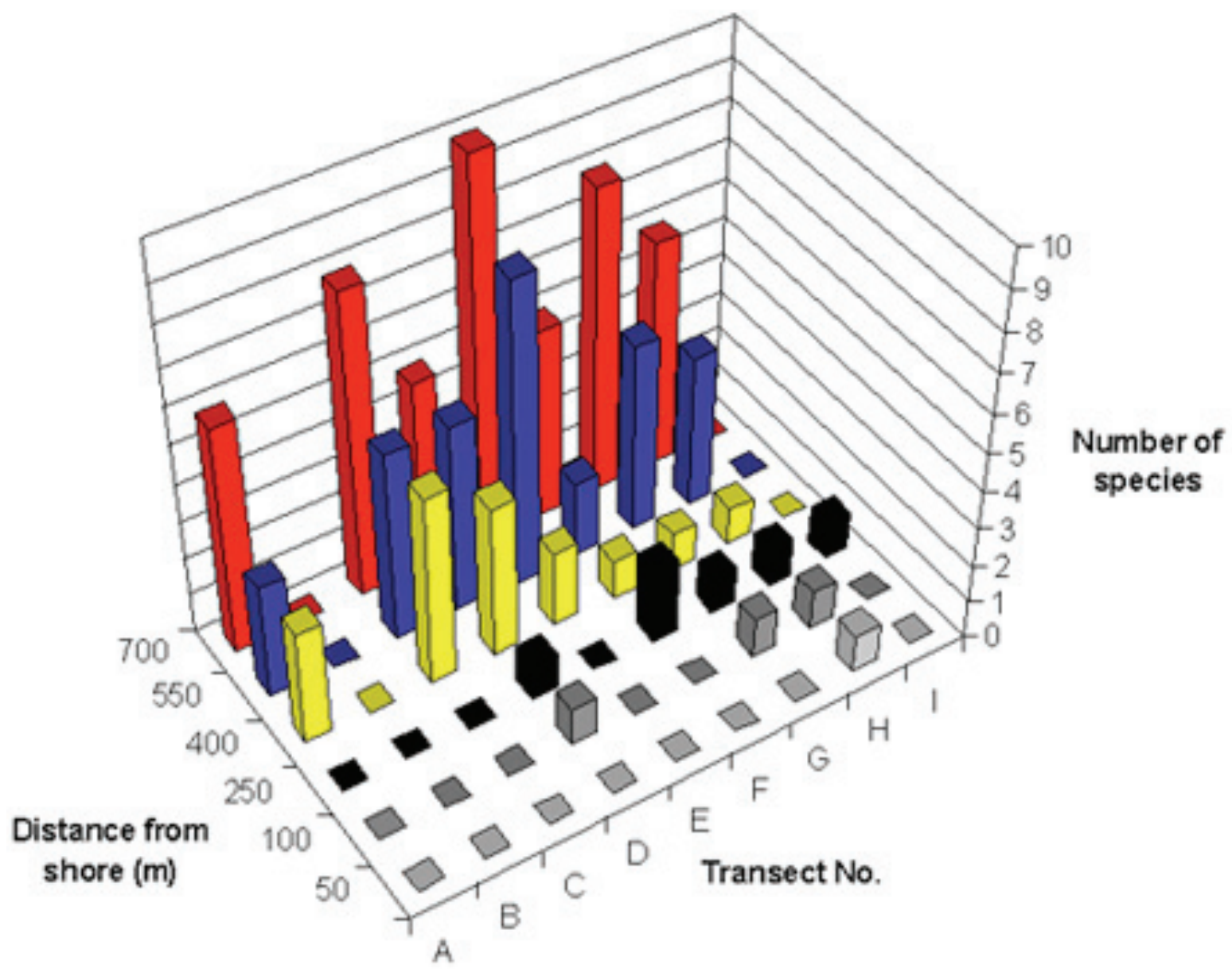

Figure 5. Graph showing species richness at USGS survey sites.

Inshore sites are comprised primarily of fine grain silt and sand (Appendix I). The native seagrass, Halophila Hawaiiana was only recorded out to $100 \mathrm{~m}$ from shore on transect I, located at Kapa'akea. Average coral cover at CRAMP/RAT stations was high at Kamalo (53.5\%) and Kakahai'a (61.6\%) declining dramatically at Kamiloloa (6.7\%).

\section{Trends and patterns}

When working with numerous parameters, multivariate techniques are commonly used to group similar sets of samples. This type of analysis is highly efficient in summarizing data for intrinsic analysis of ecological communities (Gauch 1982). Multivariate analysis can reveal the distribution of species along environmental gradients, highlight patterns in the data through spatial comparisons and habitat characterization, clarify habitat relationships and reveal trends and patterns with minimal expression of the noise typical in community data. With ordination techniques, similar entities are placed close to each other while dissimilar species or samples are located far apart in ordination space.

In community analysis involving large data sets that have several community gradients and high variability, detrended correspondence analysis (DCA) and non-metric multidimensional scaling (NMDS) have been shown to be highly effective (Gauch 1982; Clarke and Warwick 2001). These robust methods of multivariate analysis are relatively free from distortion and give equal emphasis to 
all data. These quantitative techniques are useful in identifying differences in community types and environmental gradients.

Detrended Correspondence Analysis (DCA) provided a quantitative presentation of the relationship between benthic communities at each transect location (Figure 6). Seagrass occurs only at nearshore stations on transect I located at Kapa'akea. This group is unique and stands alone. All of the others fall along a continuum from fine mud (left of diagram) grading into a macroalgae dominated community along an axis moving upward and to the right. A second gradient from macroalgae dominated communities (top center of chart) grades into a coral dominated community as we move downward and onto the line labeled Axis 1. Stations farthest from shore $(550 \mathrm{~m}$ and 700 $\mathrm{m})$ are close together in ordination space due to high coral cover, while the majority of nearshore stations $(50 \mathrm{~m}$ and $100 \mathrm{~m}$ ) cluster to the lower left of Figure 6 due to high percentages of fine sediment. Figure 6 shows a quantitative relationship that all of the investigators on this project have observed in a qualitative fashion. Starting from shore we wade through thick silt and mud. Moving seaward we find firmer footing with increasing amounts of coral rubble and sand on a carbonate platform. These areas just outside of the mud zone are dominated by macroalgae. As we proceed seaward we generally encounter more and more coral until we reach a coral dominated community.

All transects with the exception of B and $\mathrm{F}$ show an increase in coral cover with distance from shore after $250 \mathrm{~m}$. These two transects located at Pahoa and between One Ali'i and Kawela respectively, have little or no coral cover. Figure 7 showing transect $\mathrm{H}$ at Kamiloloa is typical of this trend. The trend of increasing coral cover with distance from shore remains unchanged at Kakahai'a (transect D) where RATs are included in the data set (Figure 8). 


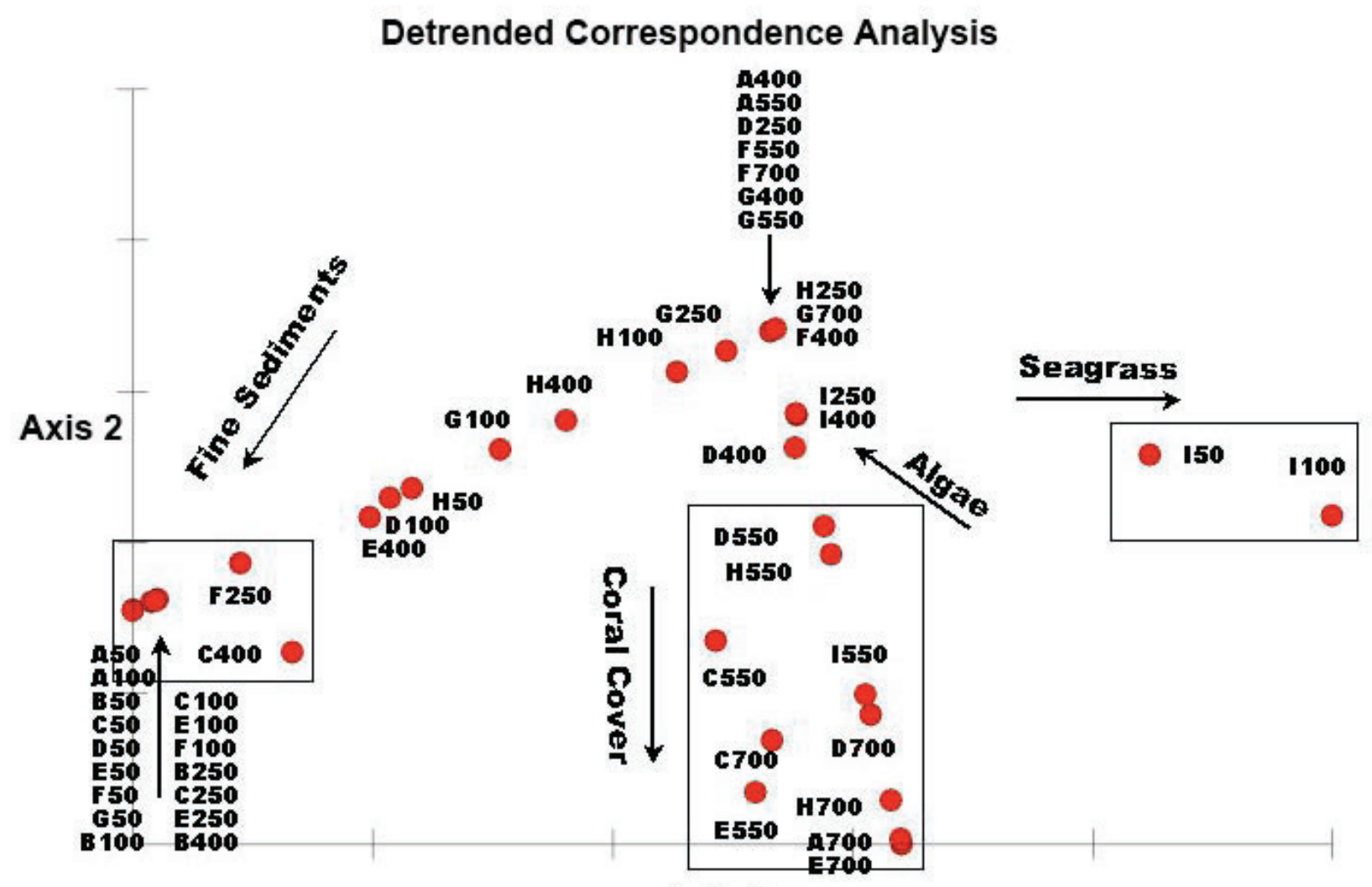

Axis 1

Figure 6. Graph showing Detrended Correspondence Analysis (DCA) of select benthic cover showing quantitative relationships between the sites as defined by biotic composition. The presence of seagrass separates I50 and I100 from the rest of the sites. All of the other sites fall along a gradient from higher coral cover (Points at the bottom of the graph on the line labeled Axis 1) to low coral cover with macroalgae (upper part of diagram) grading into macroalgae dominated sites and finally into sites that are entirely mud bottom (points on the left of the diagram falling on line labeled Axis 2). A250 and B700 were omitted by MVSP due to all 0 values. 


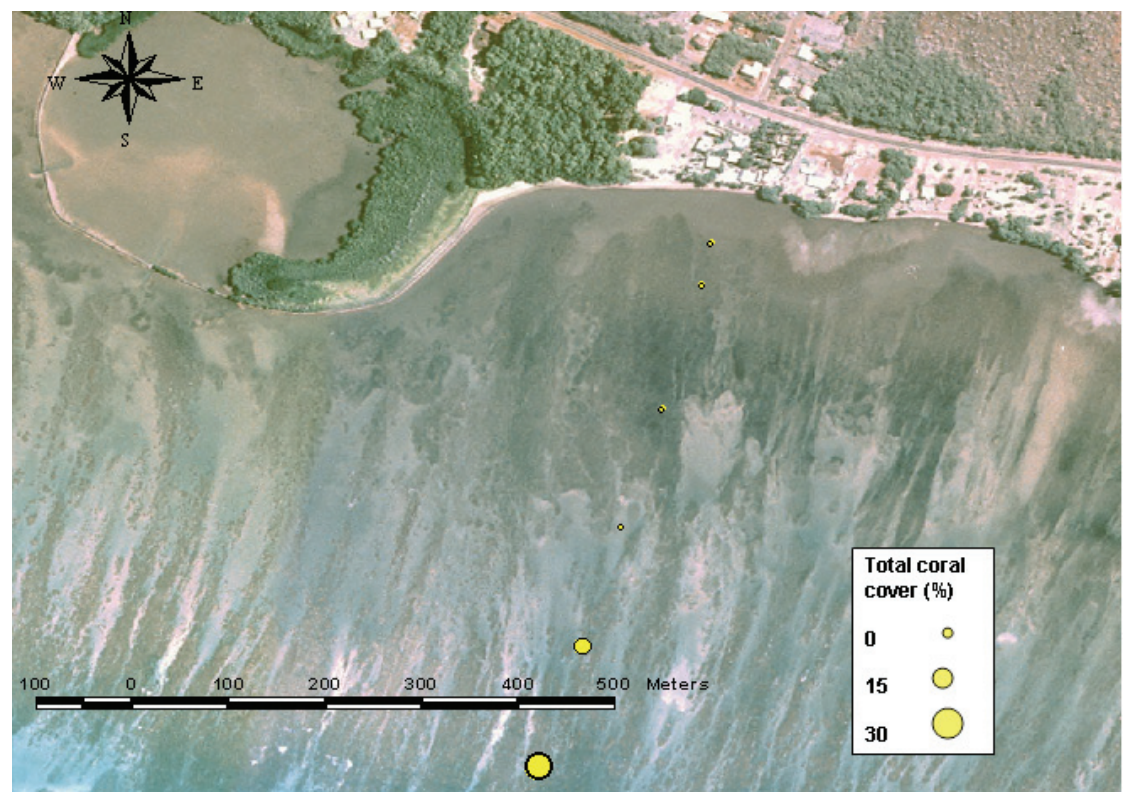

Figure 7. Aerial image showing coral cover at USGS survey sites off Kamiloloa (transect H). Cover is proportional to the size of the bubble. Typical of the majority of transects, coral cover increases with distance from shore.

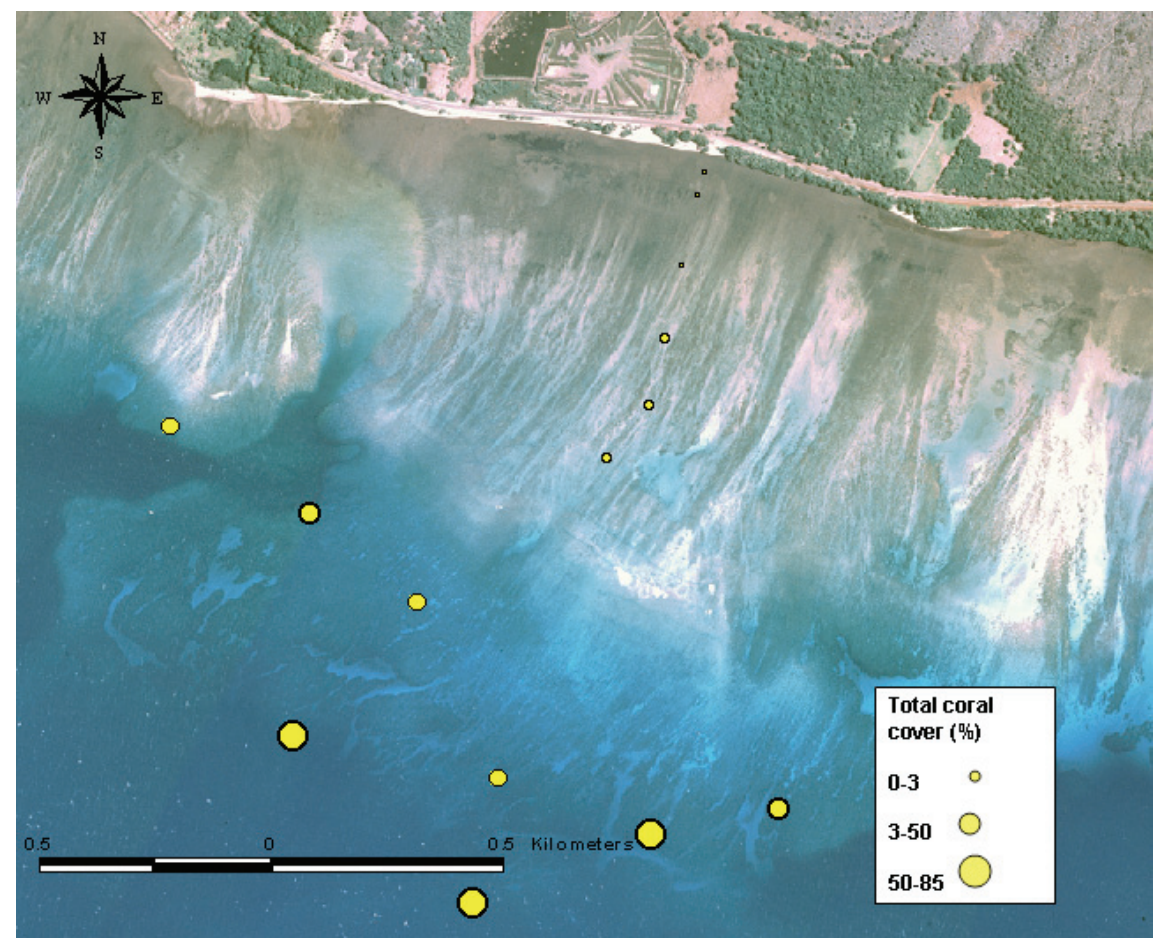

Figure 8. Aerial image showing coral cover at USGS survey sites on reef flat and eight RAT sites on reef face off Kakahai'a (transect D). Coverage is proportional to the size of the bubble. Note that coral increases with distance off shore. 


\section{Discussion}

The biological section of this project provides a quantitative description of the USGS sediment-turbidity sampling sites conducted on the reef flat. In general, coral cover on the reef flat was observed to increase with distance from shore as described previously by Jokiel et al. (in press). Figure 9 shows the general distribution of corals on the south Moloka'i reef from the reef flat to the shelf. However, the sampling sites established for the turbidity-sediment studies were confined to the reef flat and did not address conditions on the reef crest and forereef. The relationship between conditions on the reef flat and conditions farther offshore has been summarized by Jokiel et al. (in press).

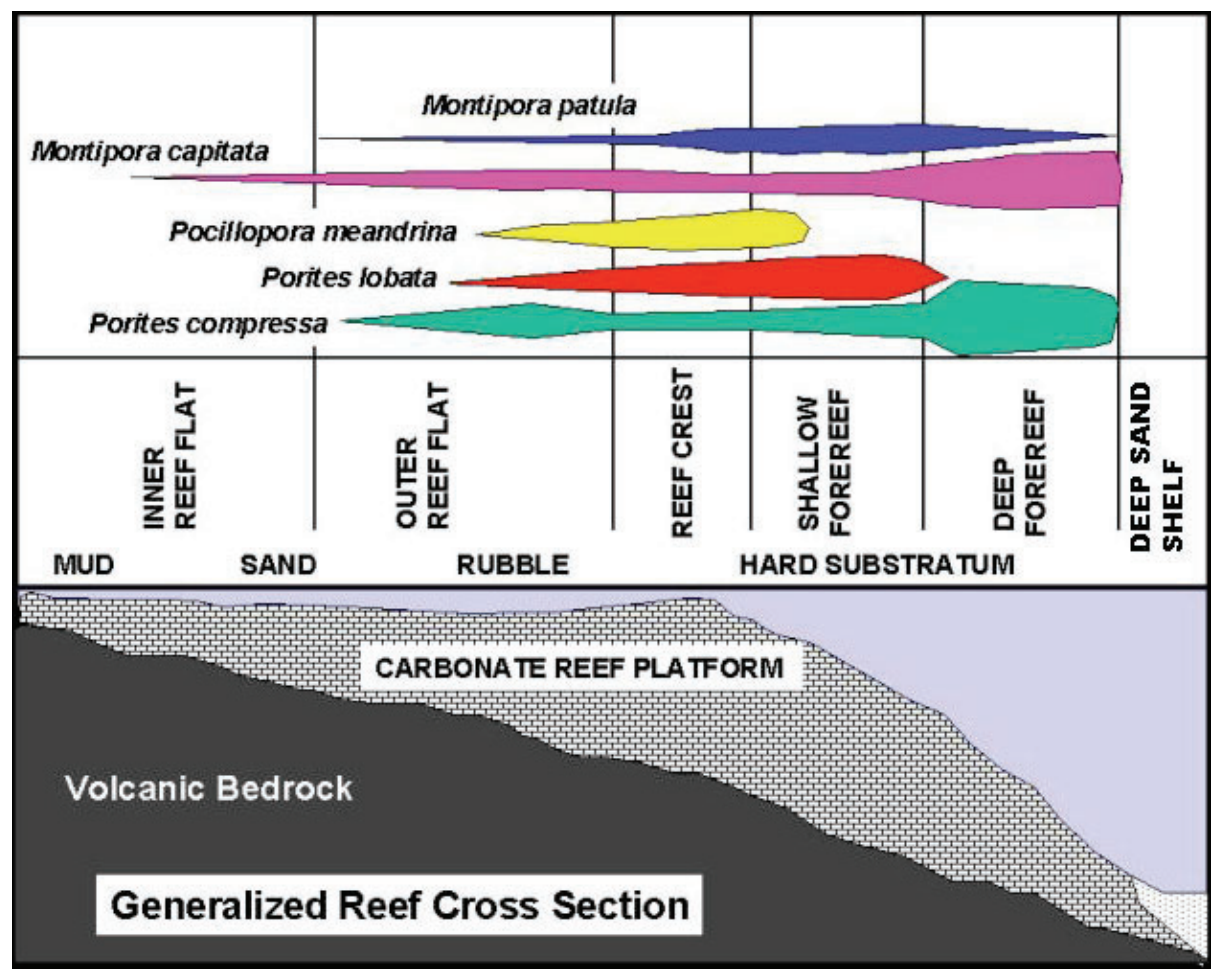

Figure 9. Generalized cross-section of the south Moloka'i reef showing coral cover increasing with distance from shore (from Jokiel et al. in press).

\section{Summary}

1. Benthic data were taken at each USGS sampling site in a manner that will allow future detection of change at each location.

2. The biological communities reflect geophysical conditions at each site. Corals are found on the outer reef flat in areas not impacted by the sediment.

3. Reduction of land-derived sediment delivery onto the reef flat will gradually improve water quality and environmental conditions for coral development. The present zone of live coral will gradually extend shoreward if conditions improve.

4. Reduction in terrigenous sediment delivery will benefit the coral reef communities on the forereef between One Ali'i and Kaunakakai as well as on the reef flat along the entire stretch of shoreline. 


\section{References}

Brown, E. K., Cox, E.F., Tissot, B., Jokiel, P. L., Rodgers, K.S., Smith, W.R., and Coles, S.L. 2003. Development of benthic sampling methods for the Coral Reef Assessment and Monitoring Program (CRAMP) in Hawai'i. Pacific Science 58 (2):145-158.

Clarke, K.R., and Warwick, R.M. 2001. Change in marine communities: an approach to statistical analysis and interpretation. $2^{\text {nd }}$ edition. PRIMER-E.: Plymouth, United Kingdom.

Jokiel, P.L., Brown, E.K., Friedlander, A., Rodgers, S.K., and Smith, W.R., 2001, Hawai'i Coral Reef Initiative Coral Reef Assessment and Monitoring Program (CRAMP) Final Report 19992000: Hawai'i Institute of Marine Biology.

Jokiel, P. L., E. K. Brown, Ku'ulei S. Rodgers and William R. Smith. (in press) Reef Corals and the Coral Reefs of South Moloka'i. In: M. Field, S. Cochran-Marquez, J. Logan, and C. Storlazzi (ed.) An Atlas of South Moloka'i. USGS Scientific Investigations Report.

Gauch, H.G. Jr. 1982. Multivariate Analysis in Community Ecology.

Press Syndicate of the University of Cambridge, New York, NY. 298 pp.

Grigg, R. W. 1983. Community structure, succession and development of coral reefs in Hawai ‘. Marine Ecology Progress Series 11: 1-14. 
Appendix I: Benthic cover and coral community parameters

\begin{tabular}{|c|c|c|c|c|c|c|c|c|c|c|c|}
\hline $\begin{array}{c}\text { Transect/m } \\
\text { offshore }\end{array}$ & algae & coralline & substrate & turf & coral & seagrass & sand & silt & rubble & richness & diversity \\
\hline A50 & 0.00 & 0.00 & 0.00 & 0.00 & 0.00 & 0.00 & 5.30 & 94.70 & 0.00 & 0.00 & 0.00 \\
\hline A100 & 0.32 & 0.00 & 0.00 & 1.47 & 0.00 & 0.00 & 87.70 & 10.50 & 0.00 & 0.00 & 0.00 \\
\hline $\mathbf{A 2 5 0}$ & 0.00 & 0.00 & 0.00 & 1.47 & 0.00 & 0.00 & 98.53 & 0.00 & 0.00 & 0.00 & 0.00 \\
\hline $\mathbf{A 4 0 0}$ & 1.26 & 0.42 & 0.00 & 5.05 & 0.00 & 0.00 & 34.60 & 0.00 & 58.68 & 0.00 & 0.00 \\
\hline $\mathbf{A 5 5 0}$ & 0.42 & 7.26 & 0.00 & 6.00 & 0.00 & 0.00 & 1.16 & 0.00 & 85.16 & 0.00 & 0.00 \\
\hline A700 & 0.00 & 4.56 & 0.00 & 0.67 & 5.56 & 0.00 & 9.67 & 0.00 & 79.22 & 3.00 & 0.97 \\
\hline B50 & 0.00 & 0.00 & 0.00 & 0.00 & 0.00 & 0.00 & 0.00 & 100.00 & 0.00 & 0.00 & 0.00 \\
\hline B100 & 0.00 & 0.00 & 0.00 & 0.00 & 0.00 & 0.00 & 0.00 & 100.00 & 0.00 & 0.00 & 0.00 \\
\hline B250 & 0.11 & 0.00 & 0.00 & 0.00 & 0.00 & 0.00 & 0.00 & 99.78 & 0.11 & 0.00 & 0.00 \\
\hline B400 & 2.25 & 0.00 & 0.00 & 1.53 & 0.00 & 0.00 & 39.78 & 54.81 & 1.64 & 0.00 & 0.00 \\
\hline B550 & 0.00 & 0.00 & 0.00 & 0.00 & 0.00 & 0.00 & 100.00 & 0.00 & 0.00 & 0.00 & 0.00 \\
\hline B700 & 0.00 & 0.00 & 0.00 & 0.00 & 0.00 & 0.00 & 0.00 & 0.00 & 100.00 & 0.00 & 0.00 \\
\hline C50 & 0.00 & 0.00 & 0.00 & 0.00 & 0.00 & 0.00 & 0.00 & 100.00 & 0.00 & 0.00 & 0.00 \\
\hline C100 & 0.00 & 0.00 & 0.00 & 0.00 & 0.00 & 0.00 & 0.00 & 100.00 & 0.00 & 0.00 & 0.00 \\
\hline $\mathrm{C} 250$ & 1.41 & 0.00 & 1.65 & 5.65 & 0.00 & 0.00 & 52.59 & 38.71 & 0.00 & 0.00 & 0.00 \\
\hline C400 & 0.78 & 0.00 & 8.56 & 0.11 & 10.78 & 0.00 & 24.00 & 43.56 & 12.22 & 3.00 & 0.91 \\
\hline C550 & 4.74 & 0.00 & 23.29 & 0.00 & 7.69 & 0.00 & 33.83 & 2.95 & 27.50 & 3.00 & 0.97 \\
\hline C700 & 2.24 & 0.20 & 19.12 & 0.00 & 12.00 & 0.00 & 53.95 & 2.44 & 10.05 & 5.00 & 0.60 \\
\hline D50 & 0.00 & 0.00 & 0.00 & 0.00 & 0.00 & 0.00 & 0.00 & 100.00 & 0.00 & 0.00 & 0.00 \\
\hline D100 & 31.60 & 0.00 & 0.00 & 1.60 & 0.00 & 0.00 & 13.00 & 47.20 & 6.60 & 0.00 & 0.00 \\
\hline D250 & 17.83 & 1.33 & 12.83 & 2.17 & 0.00 & 0.00 & 55.33 & 0.00 & 10.50 & 0.00 & 0.00 \\
\hline D400 & 10.55 & 1.64 & 19.27 & 1.45 & 3.09 & 0.00 & 19.09 & 0.18 & 44.73 & 2.00 & 0.47 \\
\hline D550 & 4.25 & 0.88 & 48.00 & 0.00 & 2.63 & 0.00 & 0.00 & 0.00 & 36.88 & 7.00 & 1.62 \\
\hline D700 & 1.06 & 0.47 & 43.41 & 0.00 & 3.18 & 0.00 & 0.00 & 0.00 & 51.88 & 3.00 & 0.82 \\
\hline E50 & 0.00 & 0.00 & 0.00 & 0.00 & 0.00 & 0.00 & 80.00 & 20.00 & 0.00 & 0.00 & 0.00 \\
\hline E100 & 0.00 & 0.00 & 0.00 & 0.01 & 0.00 & 0.00 & 85.00 & 14.99 & 0.00 & 0.00 & 0.00 \\
\hline E250 & 0.00 & 0.00 & 0.00 & 0.00 & 0.00 & 0.00 & 85.00 & 15.00 & 0.00 & 0.00 & 0.00 \\
\hline E400 & 4.63 & 0.01 & 0.00 & 7.25 & 0.25 & 0.00 & 40.88 & 8.50 & 7.50 & 1.00 & 0.00 \\
\hline E550 & 0.78 & 5.57 & 38.13 & 4.68 & 41.14 & 0.00 & 0.00 & 9.70 & 0.00 & 6.00 & 1.26 \\
\hline E700 & 0.44 & 30.81 & 21.93 & 1.43 & 44.85 & 0.00 & 0.55 & 0.00 & 0.00 & 5.00 & 0.98 \\
\hline F50 & 0.00 & 0.00 & 0.00 & 0.00 & 0.00 & 0.00 & 20.00 & 80.00 & 0.00 & 0.00 & 0.00 \\
\hline F100 & 0.00 & 0.00 & 0.00 & 1.33 & 0.00 & 0.00 & 79.78 & 17.78 & 1.11 & 0.00 & 0.00 \\
\hline Transect/m & algae & coralline & substrate & turf & coral & seagrass & sand & silt & rubble & richness & diversity \\
\hline
\end{tabular}




\section{offshore}

\begin{tabular}{|c|c|c|c|c|c|c|c|c|c|c|c|}
\hline F250 & 0.34 & 0.00 & 7.90 & 0.84 & 0.00 & 0.00 & 45.71 & 1.68 & 43.53 & 0.00 & 0.00 \\
\hline F400 & 1.54 & 0.31 & 8.15 & 2.00 & 0.31 & 0.00 & 31.54 & 0.00 & 56.15 & 1.00 & 0.00 \\
\hline F550 & 8.00 & 0.00 & 35.00 & 3.33 & 0.00 & 0.00 & 3.33 & 0.00 & 50.33 & 0.00 & 0.00 \\
\hline F700 & 1.54 & 1.85 & 51.08 & 1.38 & 0.00 & 0.00 & 14.62 & 0.00 & 29.54 & 0.00 & 0.00 \\
\hline G50 & 0.00 & 0.00 & 1.00 & 0.00 & 0.00 & 0.00 & 48.76 & 49.75 & 0.50 & 0.00 & 0.00 \\
\hline G100 & 12.12 & 0.00 & 0.00 & 0.00 & 0.00 & 0.00 & 78.79 & 9.09 & 0.00 & 0.00 & 0.00 \\
\hline G250 & 68.30 & 0.00 & 0.00 & 0.00 & 0.00 & 0.00 & 20.38 & 5.66 & 5.66 & 0.00 & 0.00 \\
\hline G400 & 76.00 & 0.00 & 0.00 & 0.00 & 0.00 & 0.00 & 14.00 & 0.00 & 10.00 & 0.00 & 0.00 \\
\hline G700 & 21.33 & 7.33 & 42.83 & 0.50 & 4.17 & 0.00 & 1.17 & 0.00 & 22.67 & 2.00 & 0.28 \\
\hline H50 & 25.54 & 0.00 & 0.00 & 0.00 & 0.00 & 0.00 & 41.23 & 33.23 & 0.00 & 0.00 & 0.00 \\
\hline H100 & 47.45 & 0.00 & 0.00 & 0.00 & 0.00 & 0.00 & 44.00 & 8.55 & 0.00 & 0.00 & 0.00 \\
\hline H250 & 79.08 & 0.00 & 0.00 & 0.00 & 0.00 & 0.00 & 20.31 & 0.62 & 0.00 & 0.00 & 0.00 \\
\hline H400 & 5.64 & 0.00 & 0.00 & 3.45 & 0.00 & 0.00 & 88.18 & 2.73 & 0.00 & 0.00 & 0.00 \\
\hline H550 & 17.00 & 1.67 & 42.33 & 1.22 & 13.22 & 0.00 & 11.33 & 0.00 & 13.22 & 0.00 & 0.00 \\
\hline H700 & 2.90 & 7.69 & 48.72 & 3.57 & 31.22 & 0.00 & 5.69 & 0.00 & 0.22 & 0.00 & 0.00 \\
\hline I100 & 8.00 & 0.00 & 0.00 & 4.00 & 0.00 & 18.00 & 70.00 & 0.00 & 0.00 & 0.00 & 0.00 \\
\hline I250 & 13.50 & 0.00 & 0.00 & 8.25 & 0.00 & 0.00 & 78.25 & 0.00 & 0.00 & 0.00 & 0.00 \\
\hline I400 & 3.10 & 0.00 & 4.00 & 0.60 & 0.00 & 0.00 & 92.00 & 0.00 & 0.30 & 0.00 & 0.00 \\
\hline I550 & 0.93 & 0.00 & 0.00 & 87.87 & 2.27 & 0.00 & 0.00 & 0.00 & 8.93 & 2.00 & 0.61 \\
\hline I700 & 0.00 & 0.00 & 68.38 & 0.00 & 0.00 & 0.00 & 31.50 & 0.00 & 0.00 & 0.13 & 0.00 \\
\hline
\end{tabular}




\section{Appendix II: Qualitative list of coral species ( $0=a b s e n t, 1=p r e s e n t)$ CORALS}

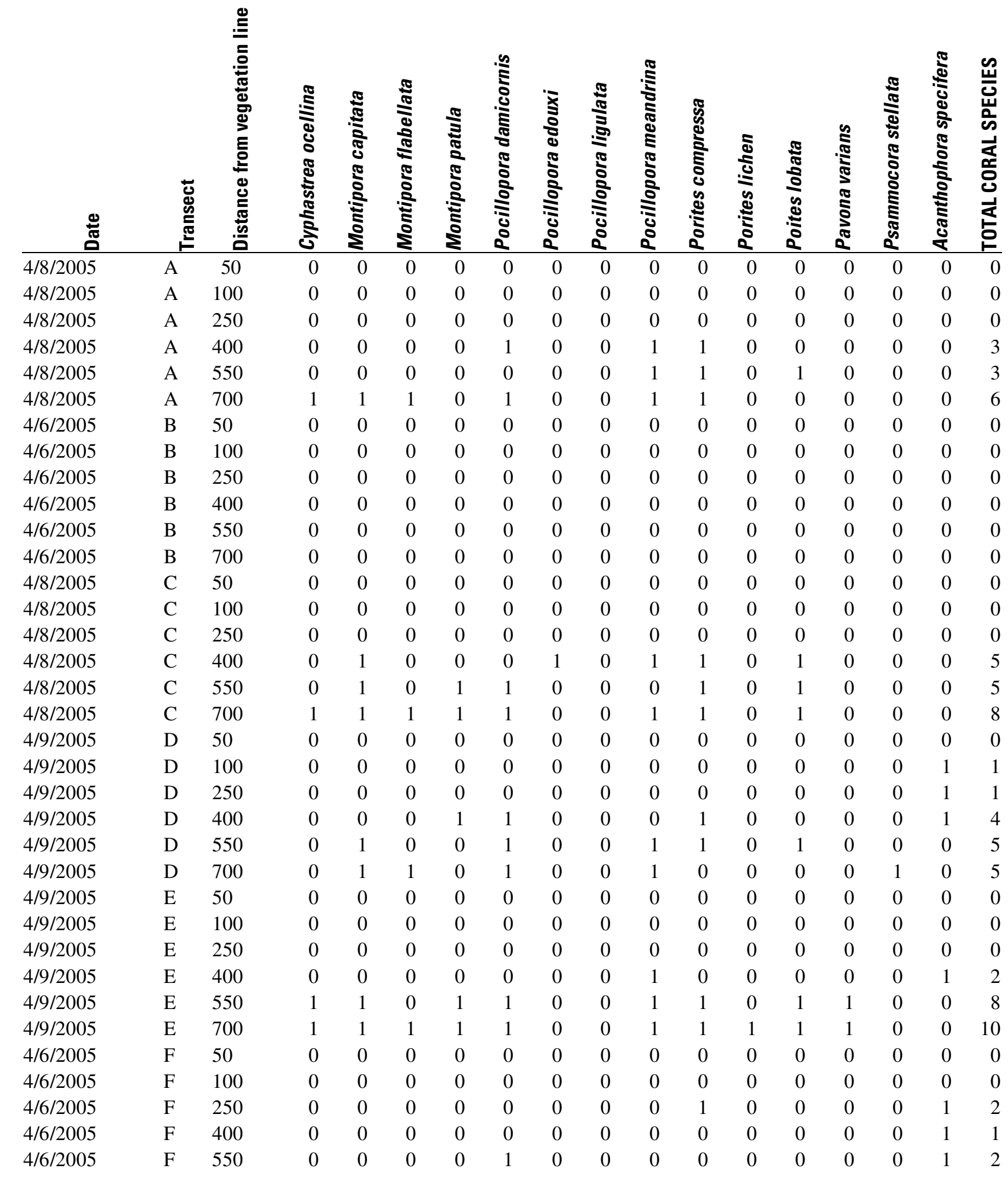


CORALS

\begin{tabular}{|c|c|c|c|c|c|c|c|c|c|c|c|c|c|c|c|c|c|}
\hline 苋 & 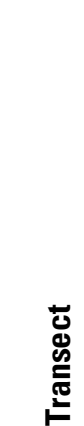 & 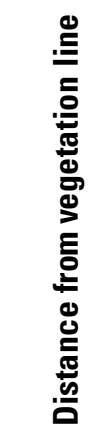 & 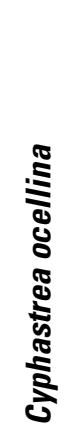 & 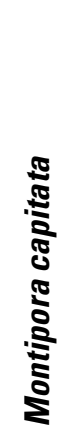 & 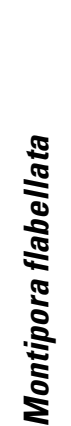 & 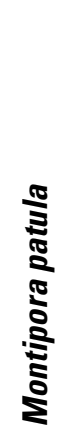 & 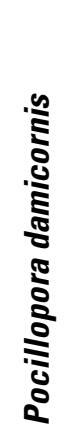 & 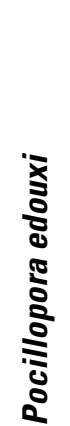 & 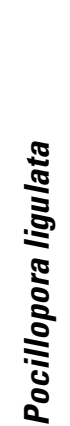 & 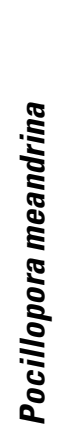 & 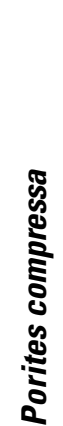 & 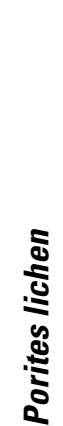 & 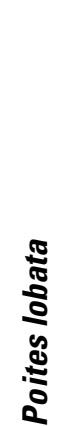 & 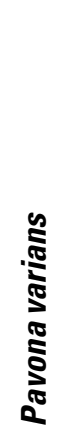 & 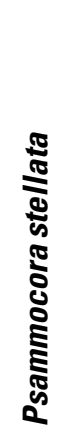 & 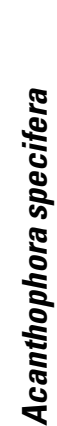 & 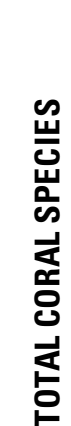 \\
\hline $4 / 6 / 2005$ & $\mathrm{~F}$ & 700 & 0 & 1 & 0 & 0 & 1 & 0 & 0 & 1 & 0 & 0 & 1 & 0 & 0 & 1 & 5 \\
\hline $4 / 6 / 2005$ & $\mathrm{G}$ & 50 & 0 & 0 & 0 & 0 & 0 & 0 & 0 & 0 & 0 & 0 & 0 & 0 & 0 & 0 & 0 \\
\hline $4 / 7 / 2005$ & $\mathrm{G}$ & 100 & 0 & 0 & 0 & 0 & 0 & 0 & 0 & 0 & 0 & 0 & 0 & 0 & 0 & 1 & 1 \\
\hline $4 / 7 / 2005$ & G & 250 & 0 & 0 & 0 & 0 & 0 & 0 & 0 & 0 & 0 & 0 & 0 & 0 & 0 & 1 & 1 \\
\hline $4 / 7 / 2005$ & $\mathrm{G}$ & 400 & 0 & 0 & 0 & 0 & 0 & 0 & 0 & 0 & 0 & 0 & 0 & 0 & 0 & 1 & 1 \\
\hline $4 / 7 / 2005$ & $\mathrm{G}$ & 550 & 0 & 0 & 0 & 0 & 1 & 0 & 0 & 1 & 1 & 0 & 0 & 0 & 1 & 1 & 5 \\
\hline $4 / 7 / 2005$ & G & 700 & 0 & 1 & 0 & 1 & 0 & 0 & 1 & 1 & 1 & 0 & 1 & 0 & 1 & 1 & 8 \\
\hline $4 / 7 / 2005$ & $\mathrm{H}$ & 50 & 0 & 0 & 0 & 0 & 0 & 0 & 0 & 0 & 0 & 0 & 0 & 0 & 0 & 1 & 1 \\
\hline $4 / 7 / 2005$ & $\mathrm{H}$ & 100 & 0 & 0 & 0 & 0 & 0 & 0 & 0 & 0 & 0 & 0 & 0 & 0 & 0 & 1 & 1 \\
\hline $4 / 7 / 2005$ & $\mathrm{H}$ & 250 & 0 & 0 & 0 & 0 & 0 & 0 & 0 & 0 & 0 & 0 & 0 & 0 & 0 & 1 & 1 \\
\hline $4 / 7 / 2005$ & $\mathrm{H}$ & 400 & 0 & 0 & 0 & 0 & 0 & 0 & 0 & 0 & 0 & 0 & 0 & 0 & 0 & 1 & 1 \\
\hline $4 / 7 / 2005$ & $\mathrm{H}$ & 550 & 0 & 0 & 0 & 1 & 0 & 0 & 0 & 1 & 1 & 0 & 0 & 1 & 0 & 0 & 4 \\
\hline $4 / 7 / 2005$ & $\mathrm{H}$ & 700 & 0 & 1 & 0 & 1 & 1 & 0 & 0 & 1 & 0 & 0 & 1 & 1 & 0 & 0 & 6 \\
\hline $4 / 7 / 2005$ & I & 50 & 0 & 0 & 0 & 0 & 0 & 0 & 0 & 0 & 0 & 0 & 0 & 0 & 0 & 0 & 0 \\
\hline $4 / 7 / 2005$ & I & 100 & 0 & 0 & 0 & 0 & 0 & 0 & 0 & 0 & 0 & 0 & 0 & 0 & 0 & 0 & 0 \\
\hline $4 / 7 / 2005$ & I & 250 & 0 & 0 & 0 & 0 & 0 & 0 & 0 & 0 & 0 & 0 & 0 & 0 & 0 & 1 & 1 \\
\hline $4 / 7 / 2005$ & I & 400 & 0 & 0 & 0 & 0 & 0 & 0 & 0 & 0 & 0 & 0 & 0 & 0 & 0 & 0 & 0 \\
\hline $4 / 7 / 2005$ & I & 550 & 0 & 0 & 0 & 0 & 0 & 0 & 0 & 0 & 0 & 0 & 0 & 0 & 0 & 0 & 0 \\
\hline $4 / 7 / 2005$ & I & 700 & 0 & 0 & 0 & 0 & 0 & 0 & 0 & 0 & 0 & 0 & 0 & 0 & 0 & 0 & 0 \\
\hline
\end{tabular}




\section{Appendix III: Qualitative list of algal species (0=absent, 1=present)}

ALGAE

\begin{tabular}{|c|c|c|c|c|c|c|c|c|c|c|c|c|c|c|c|c|c|c|c|c|c|c|c|c|c|c|c|c|c|c|c|}
\hline Iّ & 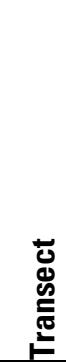 & 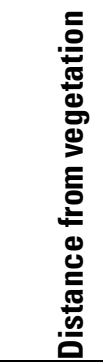 & 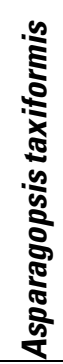 & 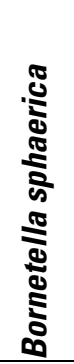 & 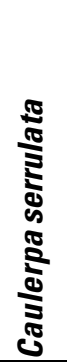 & 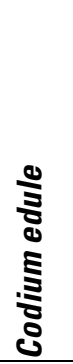 & 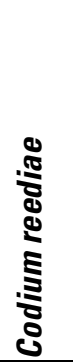 & 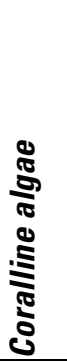 & 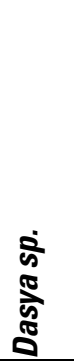 & 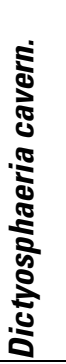 & 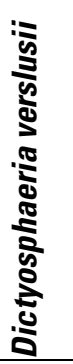 & 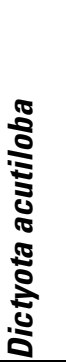 & 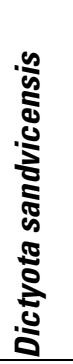 & . & 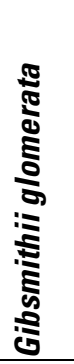 & 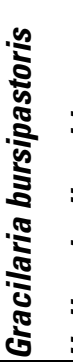 & 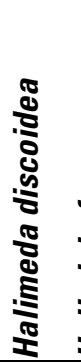 & 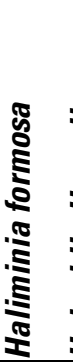 & 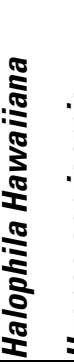 & 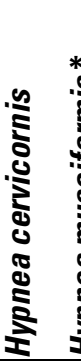 & . & 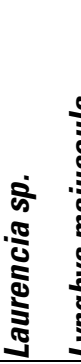 & 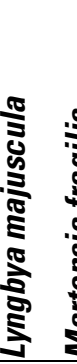 & 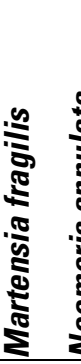 & 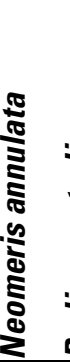 & 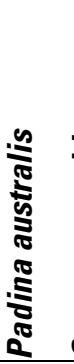 & 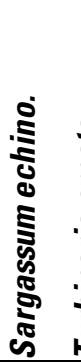 & 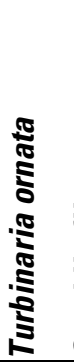 & 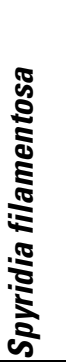 & 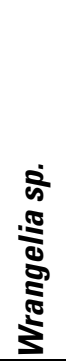 & 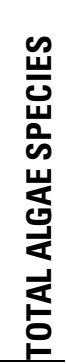 \\
\hline $4 / 8 / 2005$ & $\mathrm{~A}$ & 50 & 0 & 0 & 0 & 0 & 0 & 0 & 0 & 0 & 0 & 0 & 0 & 0 & 0 & 0 & 0 & 0 & 0 & 0 & 0 & 0 & 0 & 0 & 0 & 0 & 0 & 0 & 0 & 0 & 0 \\
\hline $4 / 8 / 2005$ & A & 100 & 0 & 0 & 0 & 0 & 0 & 0 & 0 & 0 & 0 & 0 & 0 & 0 & 0 & 0 & 0 & 0 & 0 & 0 & 0 & 0 & 0 & 0 & 0 & 0 & 0 & 0 & 0 & 0 & 0 \\
\hline $4 / 8 / 2005$ & A & 250 & 0 & 0 & 0 & 0 & 0 & 0 & 0 & 0 & 0 & 0 & 0 & 0 & 0 & 0 & 0 & 0 & 0 & 0 & 0 & 0 & 0 & 0 & 0 & 0 & 0 & 0 & 0 & 0 & 0 \\
\hline 4/8/2005 & A & 400 & 0 & 1 & 0 & 0 & 0 & 0 & 0 & 0 & 0 & 0 & 1 & 0 & 0 & 0 & 0 & 0 & 0 & 0 & 0 & 1 & 0 & 0 & 0 & 1 & 0 & 0 & 0 & 0 & 4 \\
\hline 4/8/2005 & A & 550 & 0 & 0 & 0 & 0 & 0 & 1 & 0 & 0 & 0 & 0 & 0 & 0 & 0 & 0 & 0 & 0 & 0 & 0 & 0 & 0 & 0 & 0 & 0 & 0 & 0 & 0 & 0 & 0 & 1 \\
\hline $4 / 8 / 2005$ & A & 700 & 0 & 0 & 0 & 0 & 0 & 1 & 0 & 0 & 1 & 0 & 0 & 0 & 0 & 0 & 0 & 0 & 0 & 0 & 0 & 1 & 0 & 1 & 0 & 0 & 0 & 0 & 0 & 0 & 4 \\
\hline $4 / 6 / 2005$ & B & 50 & 0 & 0 & 0 & 0 & 0 & 0 & 0 & 0 & 0 & 0 & 0 & 0 & 0 & 0 & 0 & 0 & 0 & 0 & 0 & 0 & 0 & 0 & 0 & 0 & 0 & 0 & 0 & 0 & 0 \\
\hline $4 / 6 / 2005$ & B & 100 & 0 & 0 & 0 & 0 & 0 & 0 & 0 & 0 & 0 & 0 & 0 & 0 & 0 & 0 & 0 & 0 & 0 & 0 & 0 & 0 & 0 & 0 & 0 & 0 & 0 & 0 & 0 & 0 & 0 \\
\hline $4 / 6 / 2005$ & B & 250 & 0 & 0 & 0 & 0 & 0 & 0 & 0 & 0 & 0 & 0 & 0 & 0 & 0 & 0 & 0 & 0 & 0 & 0 & 0 & 0 & 0 & 0 & 0 & 0 & 0 & 0 & 0 & 0 & 0 \\
\hline $4 / 6 / 2005$ & B & 400 & 0 & 0 & 0 & 0 & 0 & 0 & 0 & 0 & 0 & 0 & 0 & 0 & 0 & 0 & 0 & 0 & 0 & 0 & 0 & 0 & 0 & 0 & 0 & 0 & 0 & 0 & 0 & 0 & 0 \\
\hline $4 / 6 / 2005$ & B & 550 & 0 & 0 & 0 & 0 & 0 & 0 & 0 & 0 & 0 & 0 & 0 & 0 & 0 & 0 & 0 & 0 & 0 & 0 & 0 & 0 & 0 & 0 & 0 & 0 & 0 & 0 & 0 & 0 & 0 \\
\hline $4 / 6 / 2005$ & B & 700 & 0 & 0 & 0 & 0 & 0 & 0 & 0 & 0 & 0 & 0 & 0 & 0 & 0 & 0 & 0 & 0 & 0 & 0 & 0 & 0 & 0 & 0 & 0 & 0 & 0 & 0 & 0 & 0 & 0 \\
\hline $4 / 8 / 2005$ & C & 50 & 0 & 0 & 0 & 0 & 0 & 0 & 0 & 0 & 0 & 0 & 0 & 0 & 0 & 0 & 0 & 0 & 0 & 0 & 0 & 0 & 0 & 0 & 0 & 0 & 0 & 0 & 0 & 0 & 0 \\
\hline $4 / 8 / 2005$ & $\mathrm{C}$ & 100 & 0 & 0 & 0 & 0 & 0 & 0 & 0 & 0 & 0 & 0 & 0 & 0 & 0 & 0 & 0 & 0 & 0 & 0 & 0 & 0 & 0 & 0 & 0 & 0 & 0 & 0 & 0 & 0 & 0 \\
\hline $4 / 8 / 2005$ & $\mathrm{C}$ & 250 & 0 & 0 & 0 & 0 & 0 & 0 & 0 & 0 & 0 & 0 & 0 & 0 & 0 & 0 & 0 & 0 & 0 & 0 & 0 & 1 & 0 & 0 & 0 & 0 & 0 & 0 & 0 & 0 & 1 \\
\hline $4 / 8 / 2005$ & $\mathrm{C}$ & 400 & 0 & 0 & 0 & 0 & 0 & 0 & 0 & 0 & 1 & 0 & 0 & 1 & 0 & 0 & 0 & 0 & 0 & 0 & 0 & 0 & 0 & 0 & 0 & 0 & 0 & 0 & 0 & 0 & 2 \\
\hline $4 / 8 / 2005$ & C & 550 & 0 & 0 & 0 & 1 & 0 & 0 & 0 & 0 & 1 & 0 & 0 & 0 & 0 & 0 & 0 & 0 & 0 & 0 & 0 & 1 & 0 & 1 & 0 & 0 & 0 & 0 & 0 & 0 & 4 \\
\hline $4 / 8 / 2005$ & C & 700 & 0 & 0 & 0 & 0 & 0 & 1 & 0 & 1 & 0 & 0 & 0 & 1 & 0 & 0 & 0 & 0 & 0 & 0 & 0 & 0 & 0 & 1 & 0 & 0 & 0 & 0 & 0 & 0 & 4 \\
\hline $4 / 9 / 2005$ & D & 50 & 0 & 0 & 0 & 0 & 0 & 0 & 0 & 0 & 0 & 0 & 0 & 0 & 0 & 0 & 0 & 0 & 0 & 0 & 0 & 0 & 0 & 0 & 0 & 0 & 0 & 0 & 0 & 0 & 0 \\
\hline 4/9/2005 & D & 100 & 0 & 0 & 0 & 0 & 0 & 0 & 0 & 0 & 0 & 0 & 1 & 0 & 0 & 0 & 0 & 0 & 0 & 0 & 1 & 0 & 0 & 0 & 0 & 1 & 1 & 0 & 0 & 0 & 4 \\
\hline 4/9/2005 & D & 250 & 0 & 0 & 0 & 0 & 0 & 1 & 0 & 0 & 0 & 0 & 1 & 0 & 0 & 0 & 1 & 0 & 0 & 0 & 1 & 0 & 0 & 0 & 0 & 1 & 0 & 0 & 0 & 0 & 5 \\
\hline $4 / 9 / 2005$ & D & 400 & 0 & 0 & 0 & 0 & 0 & 0 & 0 & 1 & 0 & 0 & 1 & 0 & 0 & 0 & 1 & 0 & 0 & 0 & 0 & 0 & 0 & 0 & 0 & 0 & 0 & 0 & 0 & 0 & 3 \\
\hline $4 / 9 / 2005$ & D & 550 & 1 & 0 & 0 & 0 & 0 & 1 & 0 & 1 & 1 & 0 & 0 & 1 & 0 & 0 & 1 & 0 & 0 & 0 & 0 & 0 & 0 & 0 & 1 & 0 & 0 & 1 & 0 & 0 & 8 \\
\hline 4/9/2005 & $\mathrm{D}$ & 700 & 0 & 0 & 0 & 1 & 0 & 1 & 1 & 0 & 0 & 0 & 1 & 1 & 0 & 0 & 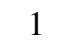 & 1 & 1 & 0 & 0 & 0 & 1 & 1 & 0 & 0 & 0 & 1 & 1 & & \\
\hline
\end{tabular}


ALGAE

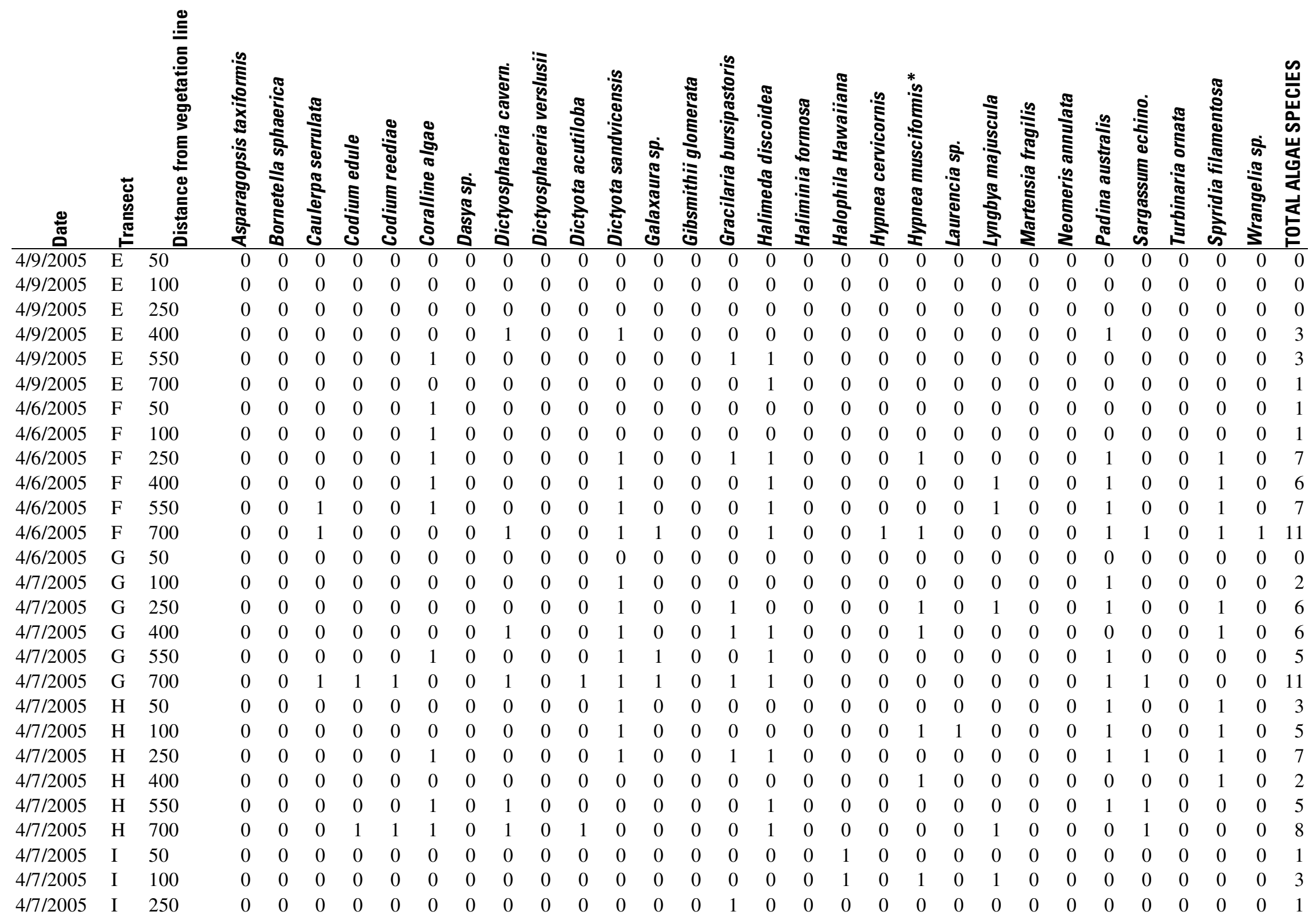


ALGAE

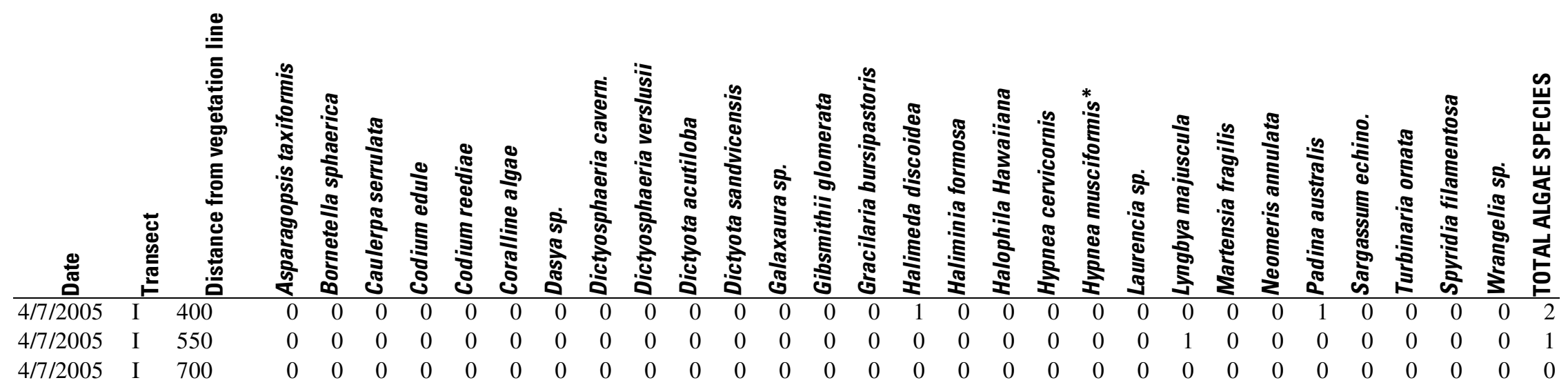

* invasive introduced species 


\section{Appendix IV: Qualitative list of fish and invertebrate species ( $0=$ absent, $1=$ present)}

Fish

Invertebrates

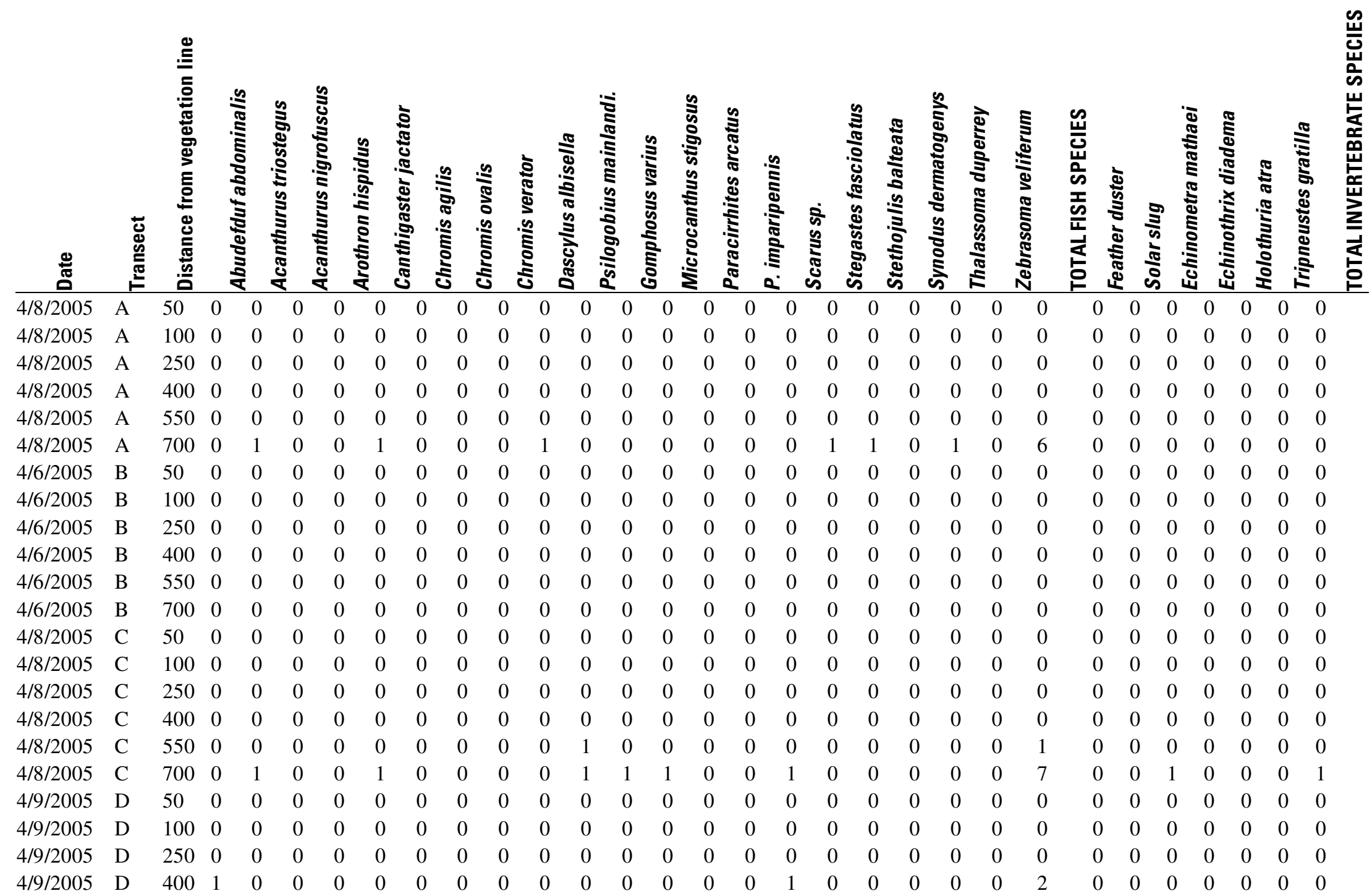




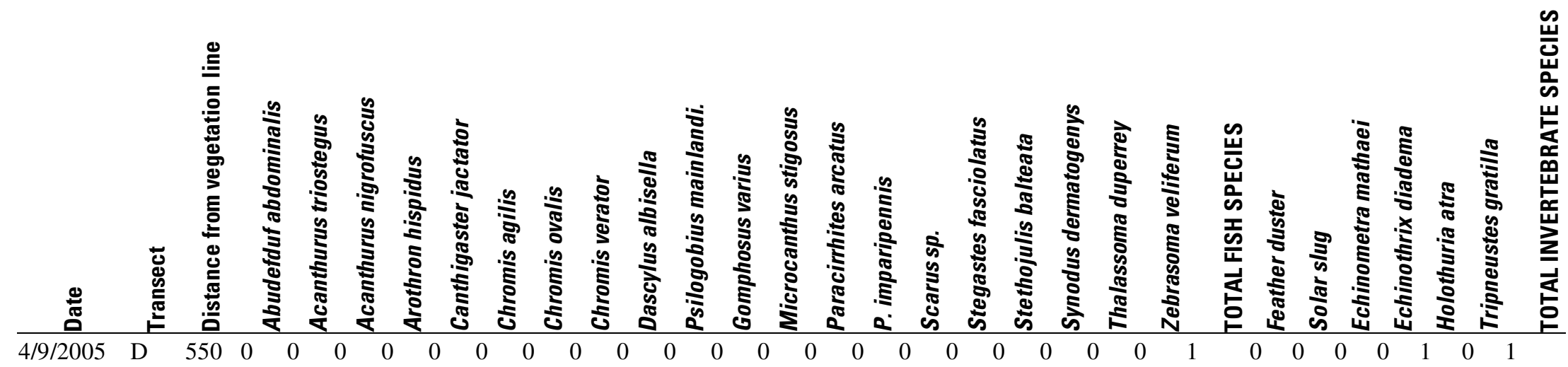

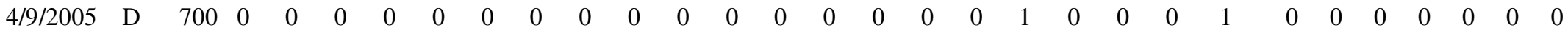

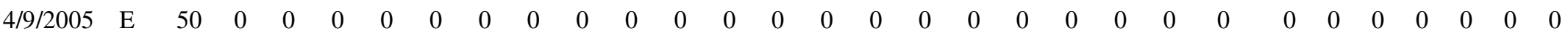
$\begin{array}{lllllllllllllllllllllllllllllllllllllllll}4 / 9 / 2005 & \mathrm{E} & 100 & 0 & 0 & 0 & 0 & 0 & 0 & 0 & 0 & 0 & 0 & 0 & 0 & 0 & 0 & 0 & 0 & 0 & 0 & 0 & 0 & 0 & 0 & 0 & 0 & 0 & 0 & 0 & 0\end{array}$

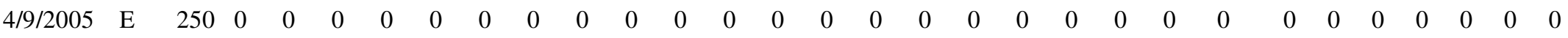

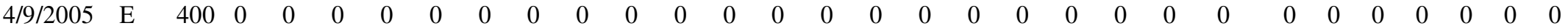
$\begin{array}{llllllllllllllllllllllllllllllllllllllll}4 / 9 / 2005 & \mathrm{E} & 550 & 1 & 1 & 1 & 0 & 0 & 0 & 0 & 0 & 0 & 0 & 0 & 0 & 0 & 0 & 0 & 0 & 0 & 0 & 0 & 1 & 4 & 0 & 0 & 0 & 0 & 0 & 0 & 0\end{array}$

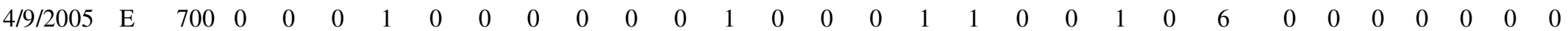

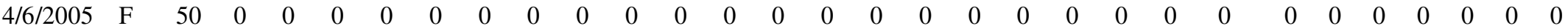

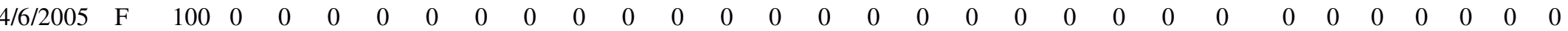

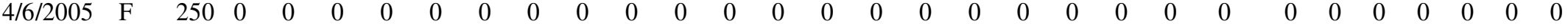

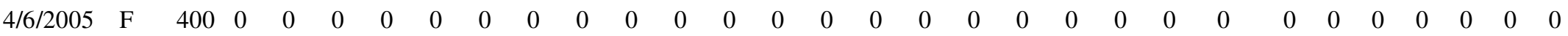
$\begin{array}{llllllllllllllllllllllllllllllllllllll}4 / 6 / 2005 & \mathrm{~F} & 550 & 1 & 1 & 0 & 0 & 0 & 0 & 0 & 0 & 0 & 0 & 0 & 0 & 0 & 0 & 0 & 0 & 0 & 1 & 1 & 0 & 5 & 0 & 0 & 1 & 0 & 0 & 0 & 1\end{array}$

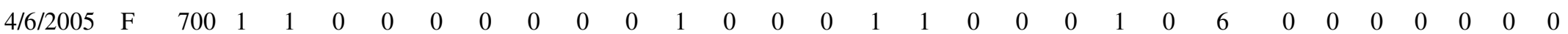
$\begin{array}{llllllllllllllllllllllllllllllllllllllllll}4 / 6 / 2005 & \mathrm{G} & 50 & 0 & 0 & 0 & 0 & 0 & 0 & 0 & 0 & 0 & 0 & 0 & 0 & 0 & 0 & 0 & 0 & 0 & 0 & 0 & 0 & 0 & 0 & 0 & 0 & 0 & 0 & 0 & 0\end{array}$

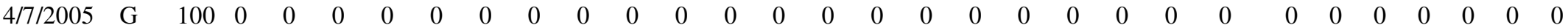
$\begin{array}{llllllllllllllllllllllllllllllllllll}4 / 7 / 2005 & \mathrm{G} & 250 & 0 & 0 & 0 & 0 & 0 & 0 & 0 & 0 & 0 & 0 & 0 & 0 & 0 & 0 & 0 & 0 & 0 & 0 & 0 & 0 & 0 & 0 & 0 & 0 & 0 & 0 & 0 & 0\end{array}$

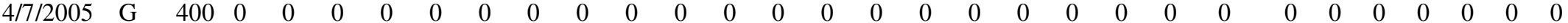
$\begin{array}{llllllllllllllllllllllllllllllllllllllll}4 / 7 / 2005 & \mathrm{G} & 550 & 1 & 1 & 0 & 0 & 0 & 0 & 0 & 0 & 0 & 1 & 0 & 0 & 0 & 1 & 0 & 0 & 0 & 1 & 1 & 0 & 6 & 0 & 0 & 0 & 0 & 0 & 0 & 0\end{array}$ $\begin{array}{llllllllllllllllllllllllllllllllllllllllll}4 / 7 / 2005 & \mathrm{G} & 700 & 1 & 1 & 0 & 0 & 0 & 0 & 1 & 0 & 0 & 1 & 0 & 1 & 0 & 0 & 0 & 0 & 0 & 1 & 1 & 0 & 7 & 0 & 0 & 0 & 0 & 0 & 0 & 0 & 0\end{array}$ $\begin{array}{llllllllllllllllllllllllllllllllllllll}4 / 7 / 2005 & \mathrm{H} & 50 & 0 & 0 & 0 & 0 & 0 & 0 & 0 & 0 & 0 & 0 & 0 & 0 & 0 & 0 & 0 & 0 & 0 & 0 & 0 & 0 & 0 & 0 & 0 & 0 & 0 & 0 & 0 & 0\end{array}$ $\begin{array}{lllllllllllllllllllllllllllllllllllllll}4 / 7 / 2005 & \mathrm{H} & 100 & 0 & 0 & 0 & 0 & 0 & 0 & 0 & 0 & 0 & 0 & 0 & 0 & 0 & 0 & 0 & 0 & 0 & 0 & 0 & 0 & 0 & 0 & 0 & 0 & 0 & 0 & 0 & 0\end{array}$ $\begin{array}{lllllllllllllllllllllllllllllllllllll}4 / 7 / 2005 & \mathrm{H} & 250 & 0 & 0 & 0 & 0 & 0 & 0 & 0 & 0 & 0 & 0 & 0 & 0 & 0 & 0 & 0 & 0 & 0 & 0 & 0 & 0 & 0 & 0 & 0 & 0 & 0 & 0 & 0 & 0\end{array}$ $\begin{array}{lllllllllllllllllllllllllllllllllll}4 / 7 / 2005 & \mathrm{H} & 400 & 0 & 0 & 0 & 0 & 0 & 0 & 0 & 0 & 0 & 0 & 0 & 0 & 0 & 0 & 0 & 0 & 0 & 0 & 0 & 0 & 0 & 0 & 0 & 0 & 0 & 0 & 0 & 0\end{array}$ 4/7/2005 


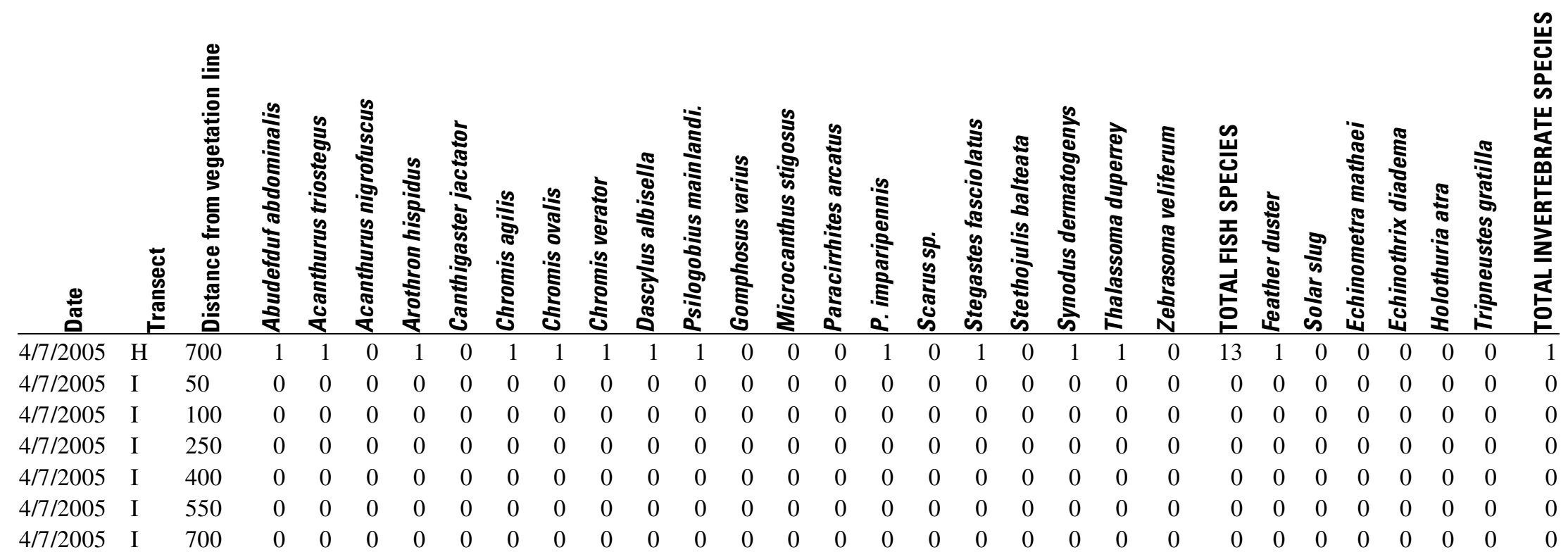


Appendix V: Summary of coral survey parameters with example images 
Appendix V: Summary of coral survey parameters with example images
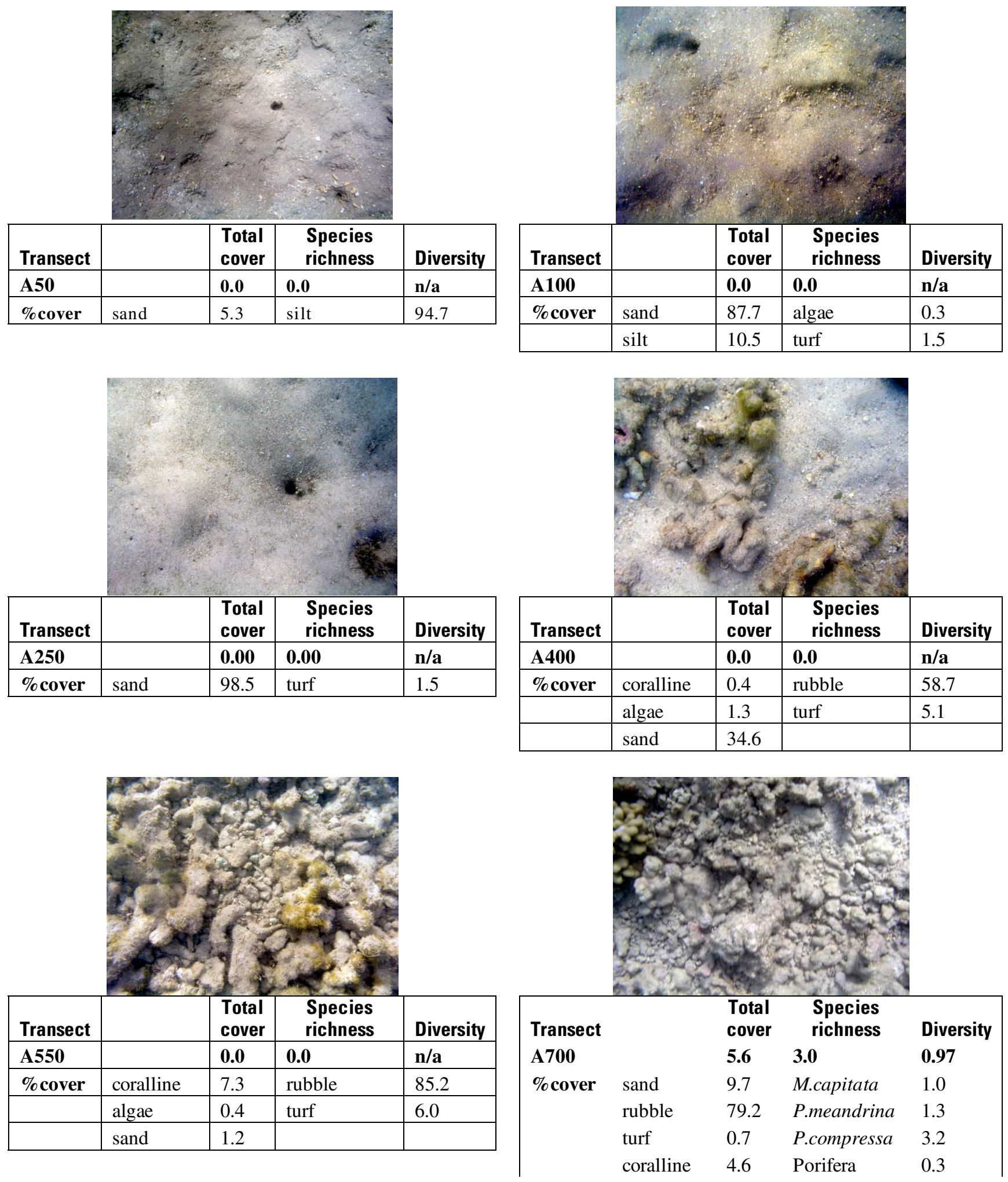

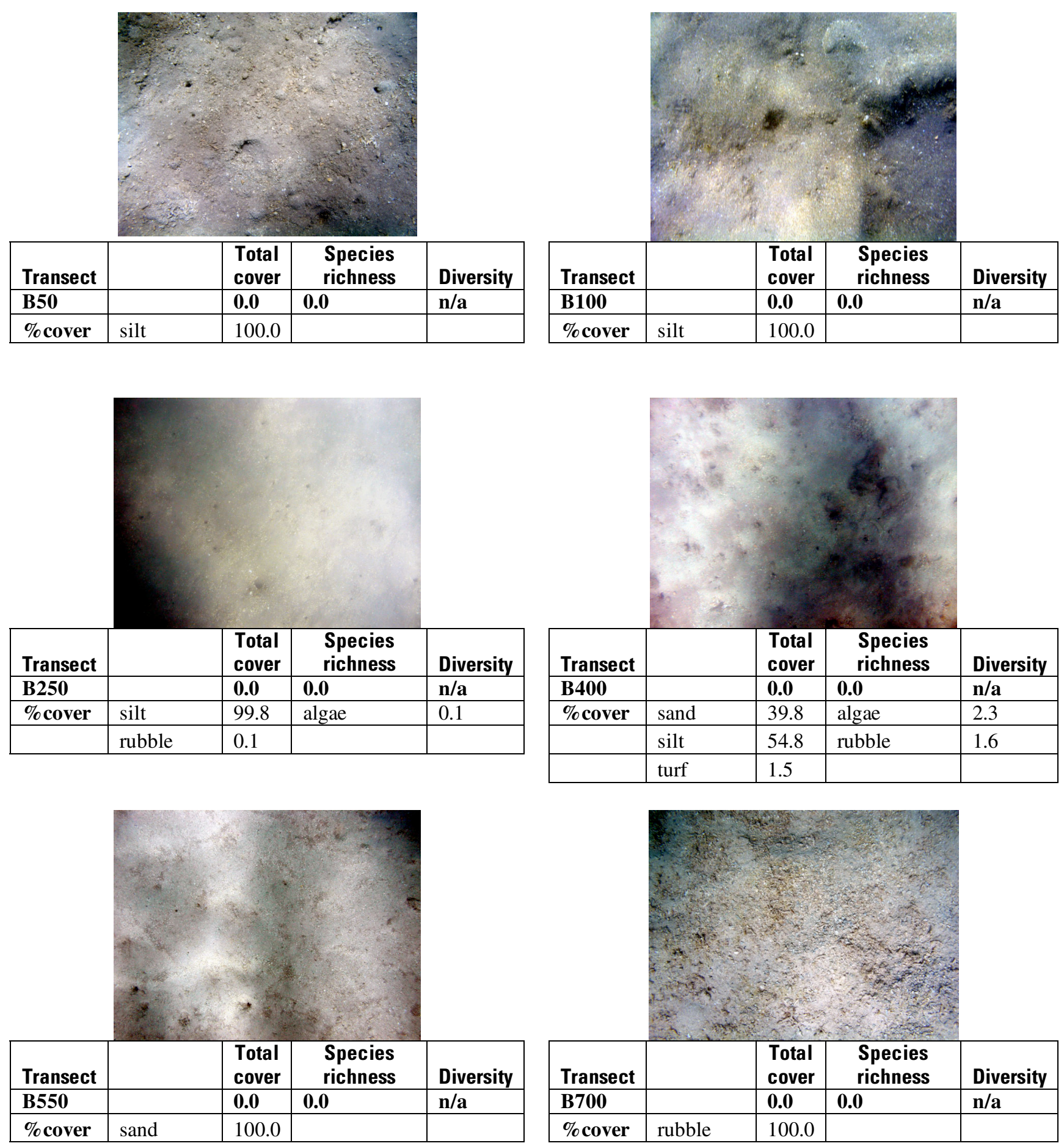

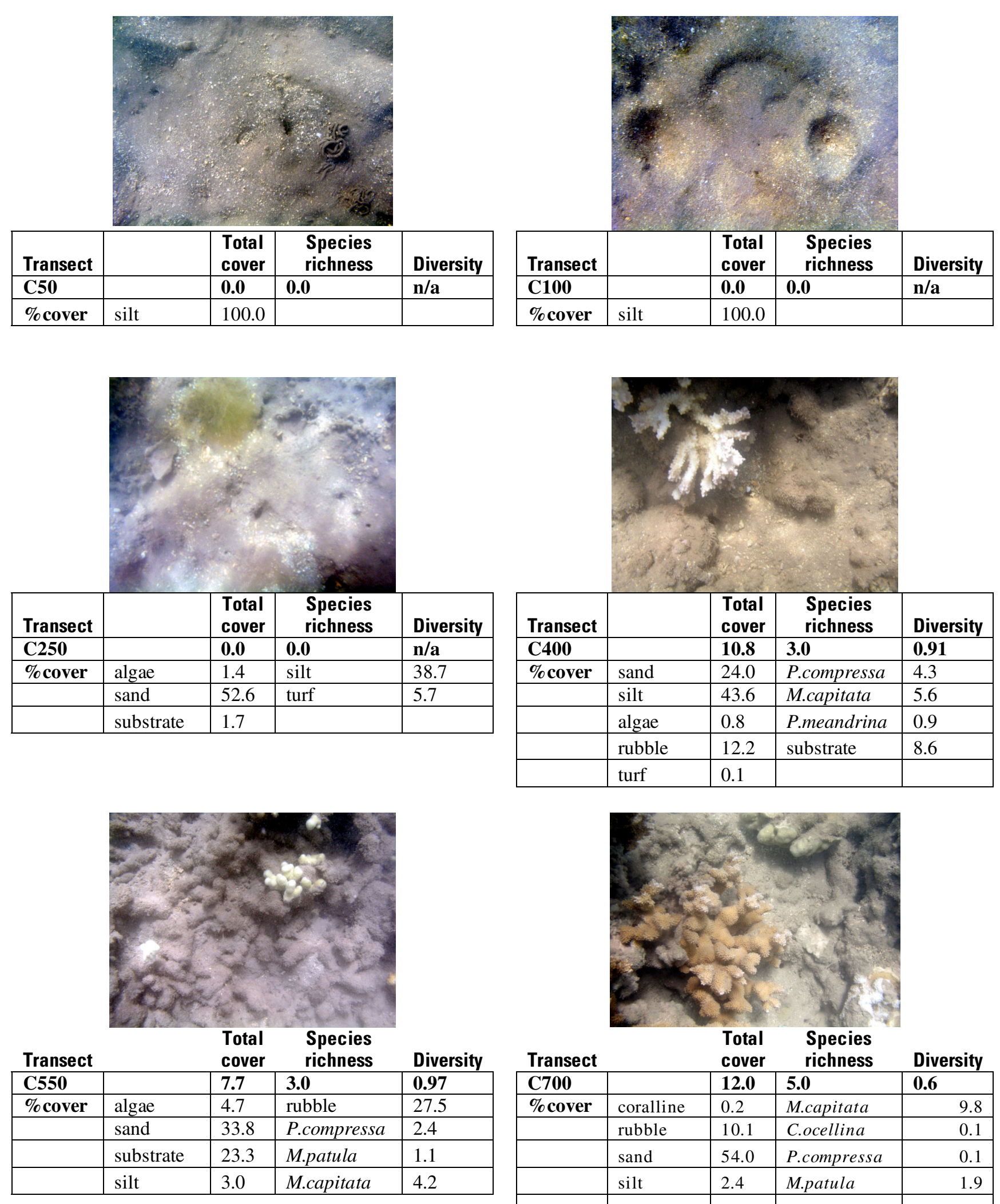

\begin{tabular}{|c|c|c|c|c|}
\hline \multicolumn{2}{|l|}{ Transect } & \multicolumn{2}{|r|}{$\begin{array}{l}\text { Species } \\
\text { richness }\end{array}$} & Diversity \\
\hline C700 & & 12.0 & 5.0 & 0.6 \\
\hline \%cover & coralline & 0.2 & M.capitata & 9.8 \\
\hline & rubble & 10.1 & C.ocellina & 0.1 \\
\hline & sand & 54.0 & P.compressa & 0.1 \\
\hline & silt & 2.4 & M.patula & 1.9 \\
\hline & substrate & 19.1 & P.damicornis & 0.2 \\
\hline & & & algae & 2.2 \\
\hline
\end{tabular}



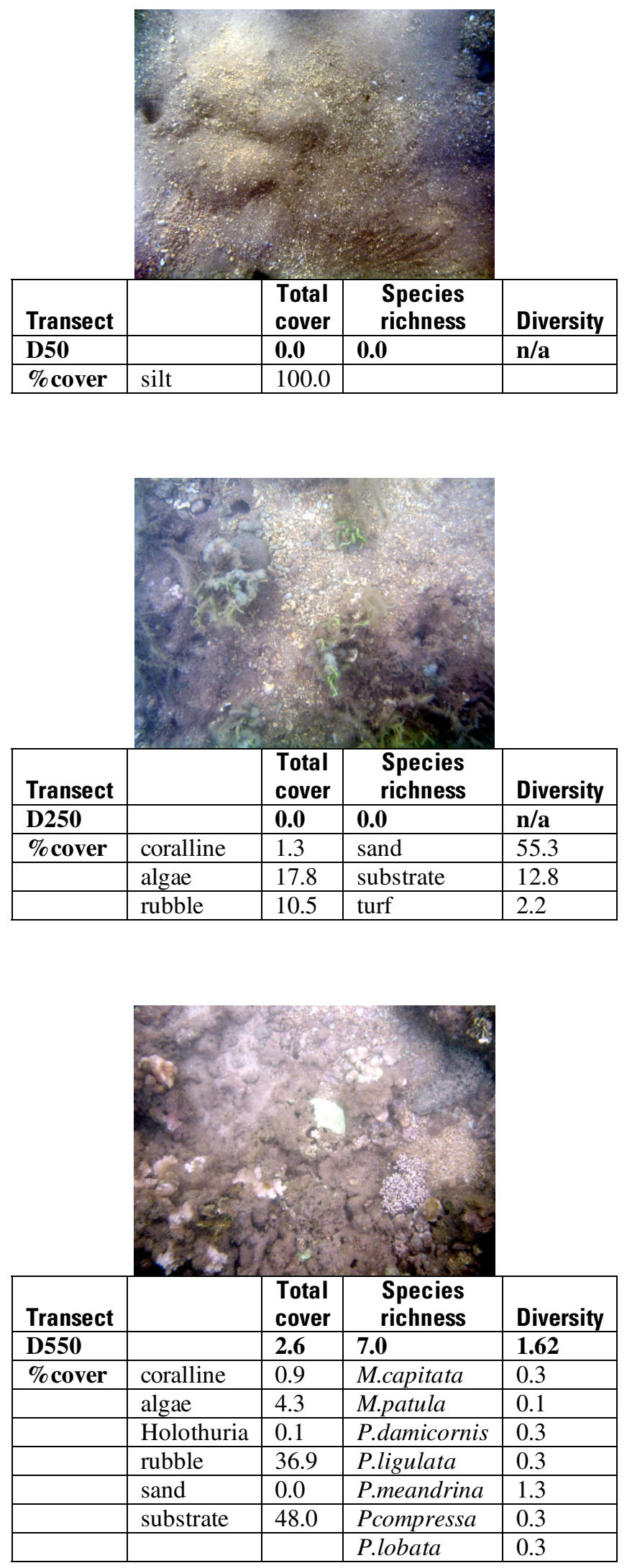
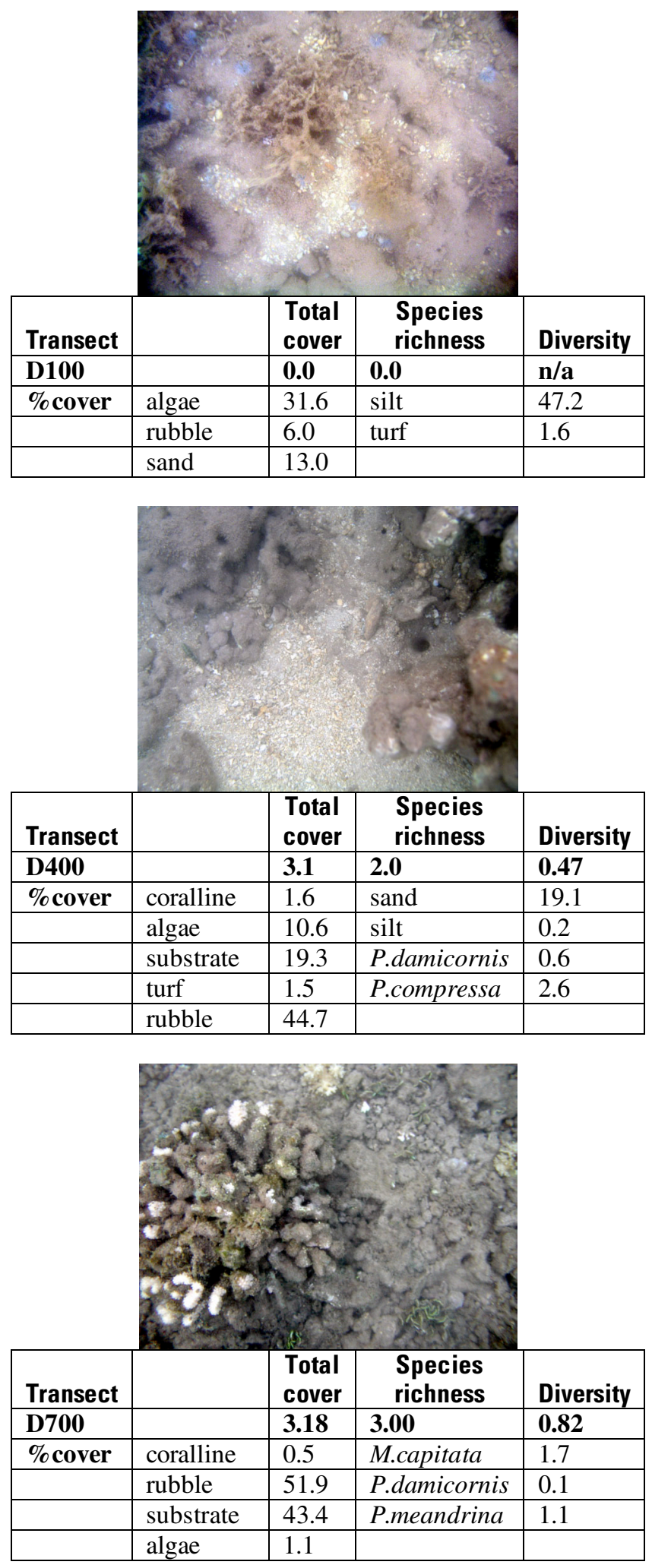

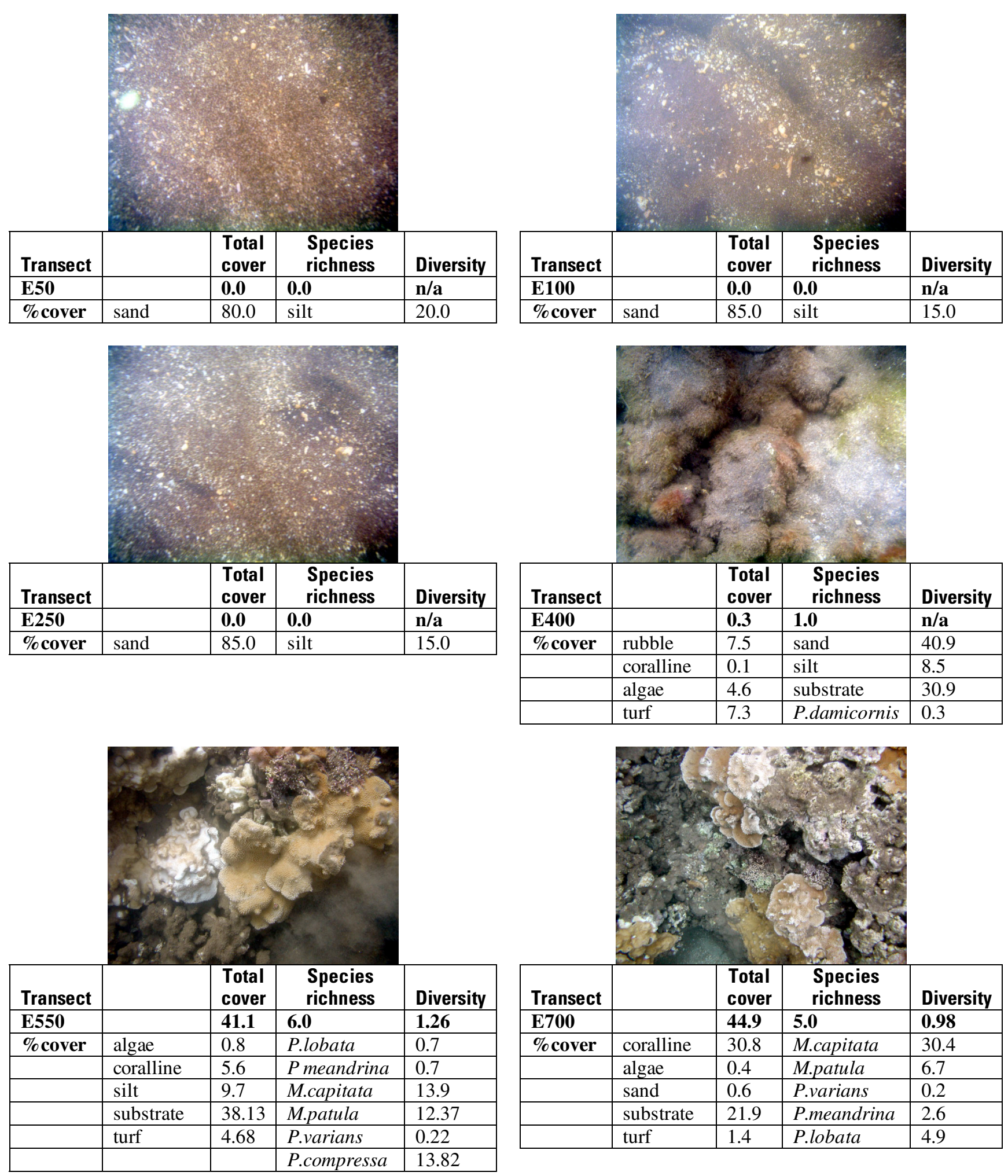

\begin{tabular}{|c|c|c|c|c|}
\hline Transect & & $\begin{array}{l}\text { Total } \\
\text { cover }\end{array}$ & $\begin{array}{l}\text { Species } \\
\text { richness }\end{array}$ & Diversity \\
\hline $\begin{array}{l}\text { E700 } \\
\end{array}$ & & 44.9 & 5.0 & 0.98 \\
\hline \%cover & coralline & 30.8 & M.capitata & 30.4 \\
\hline & algae & 0.4 & M.patula & 6.7 \\
\hline & sand & 0.6 & P.varians & 0.2 \\
\hline & substrate & 21.9 & P.meandrina & 2.6 \\
\hline & turf & 1.4 & P.lobata & 4.9 \\
\hline
\end{tabular}



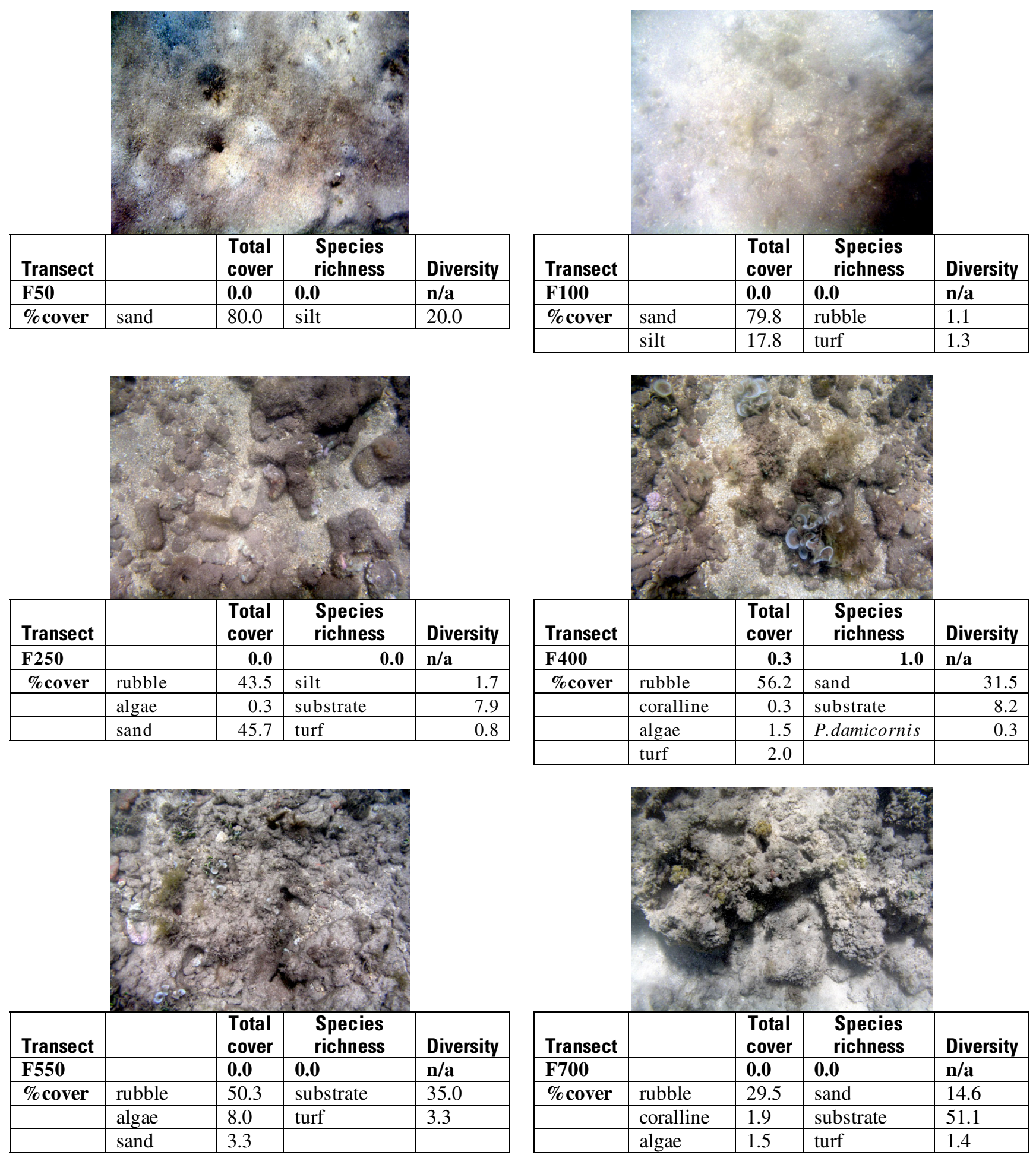

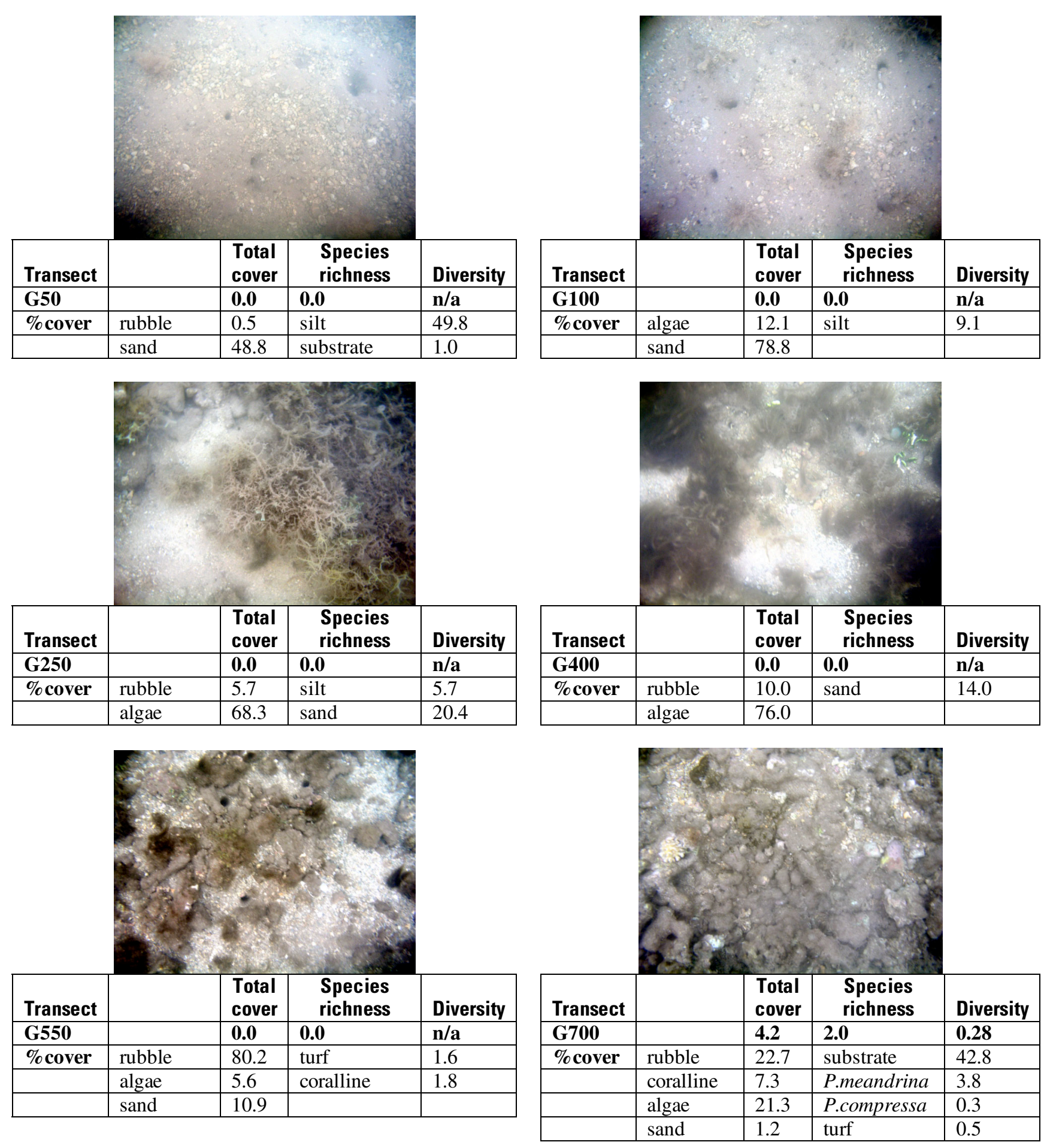

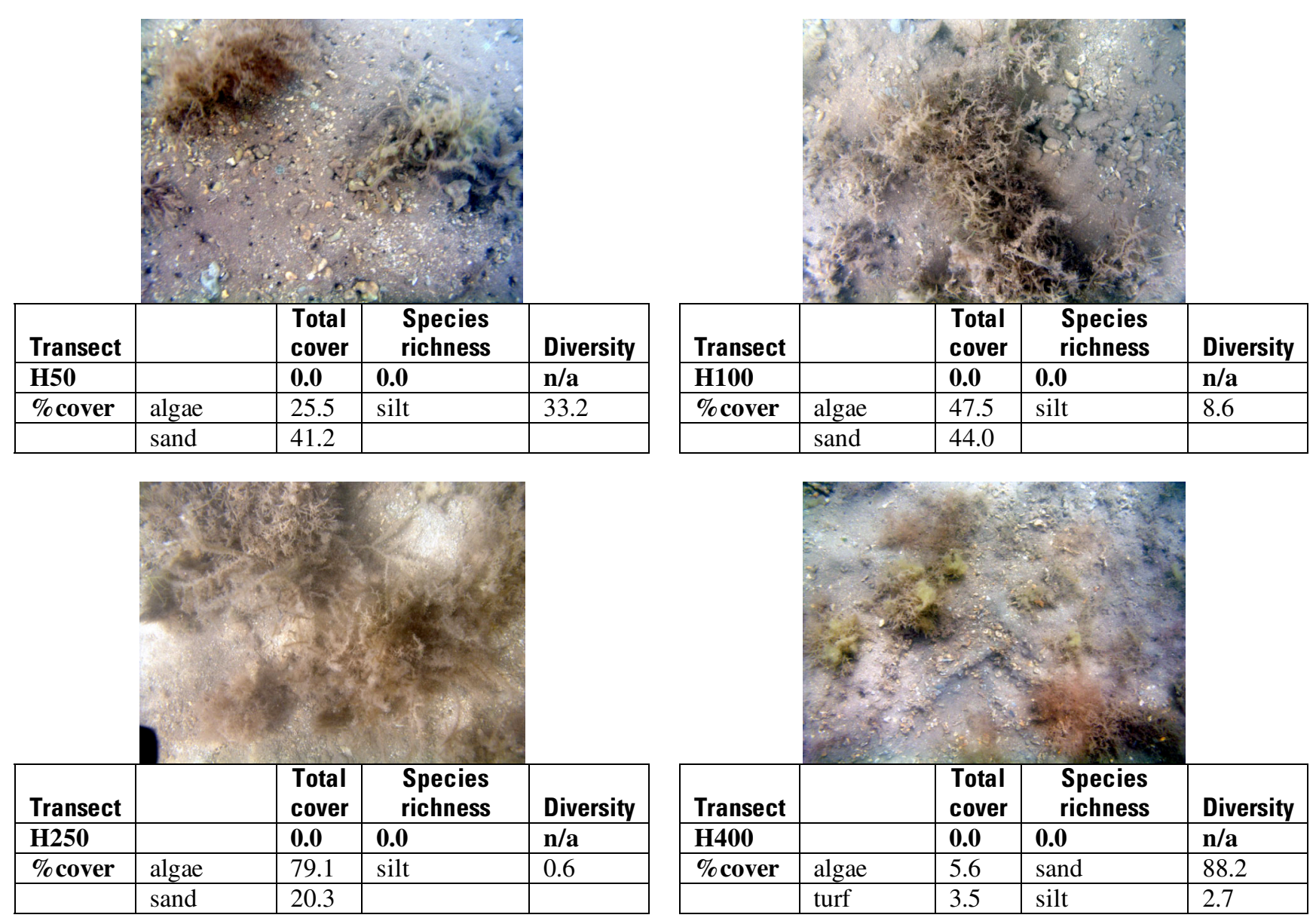

\begin{tabular}{|c|c|c|c|c|}
\hline Transect & & $\begin{array}{l}\text { Total } \\
\text { cover }\end{array}$ & $\begin{array}{l}\text { Species } \\
\text { richness }\end{array}$ & Diversity \\
\hline H550 & & 13.2 & 5.0 & 0.94 \\
\hline \multirow[t]{6}{*}{ \% cover } & rubble & 13.2 & M.capitata & 8.7 \\
\hline & coralline & 1.7 & P.damicornis & 0.4 \\
\hline & algae & 17.0 & P.meandrina & 3.3 \\
\hline & sand & 11.3 & P.compressa & 0.6 \\
\hline & substrate & 42.3 & P.stellata & 0.2 \\
\hline & turf & 1.2 & & \\
\hline
\end{tabular}

\begin{tabular}{|c|c|c|c|c|}
\hline Transect & & $\begin{array}{l}\text { Total } \\
\text { cover }\end{array}$ & $\begin{array}{l}\text { Species } \\
\text { richness }\end{array}$ & Diversity \\
\hline H700 & & 31.2 & 7.0 & 1.26 \\
\hline \multirow[t]{7}{*}{ \%cover } & rubble & 0.2 & M.capitata & 5.2 \\
\hline & coralline & 7.7 & M.patula & 2.5 \\
\hline & algae & 2.9 & P.varians & 0.1 \\
\hline & sand & 5.7 & P.meandrina & 7.4 \\
\hline & substrate & 48.7 & P.damicornis & 0.2 \\
\hline & turf & 3.6 & P.lobata & 15.7 \\
\hline & & & P.stellata & 0.1 \\
\hline
\end{tabular}



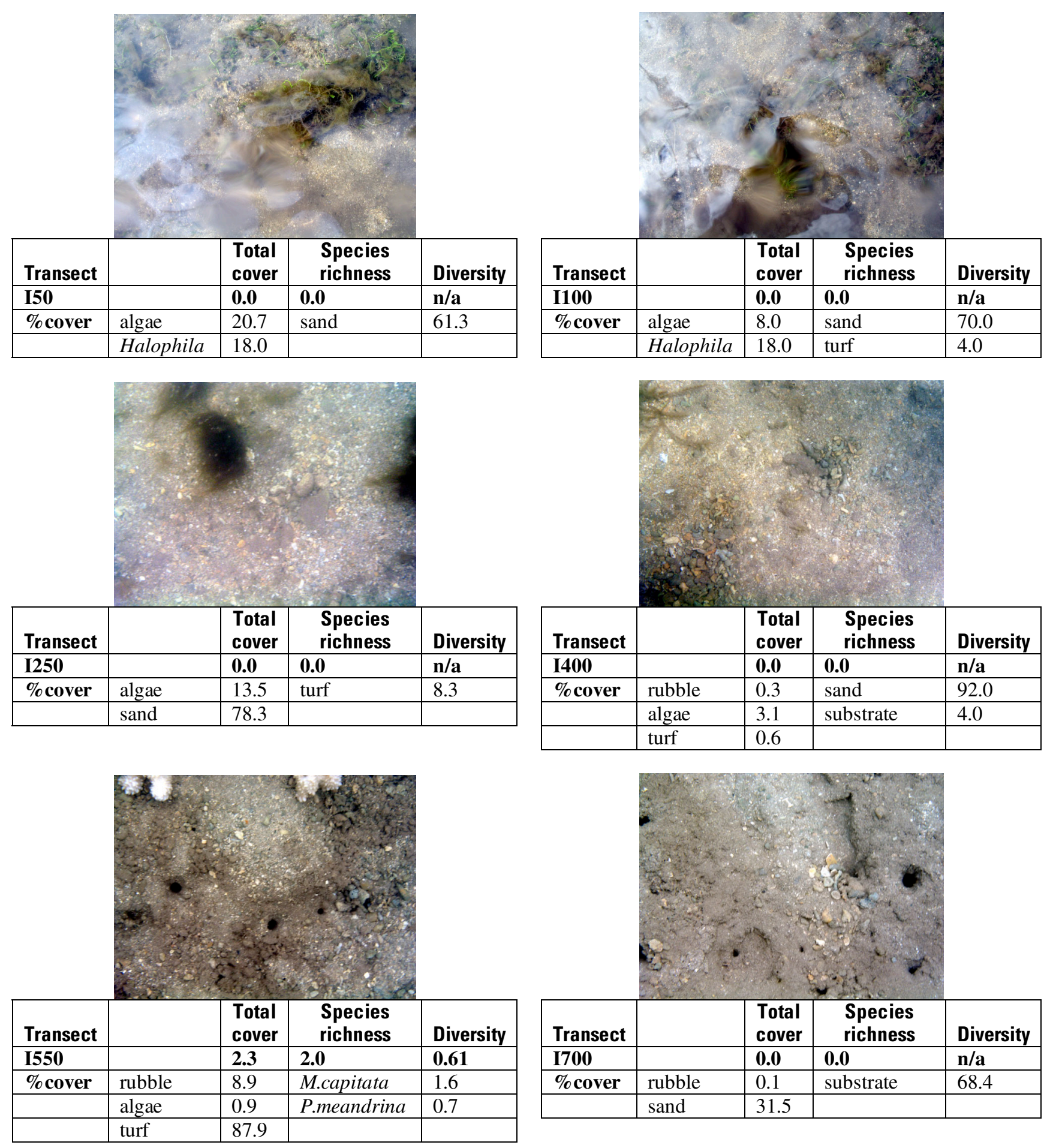